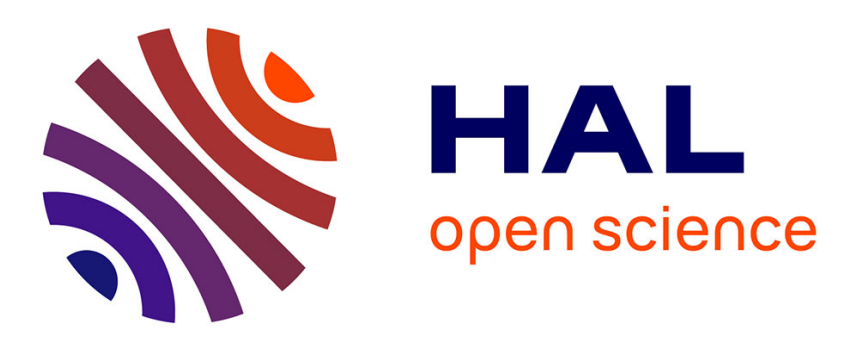

\title{
The importance of design for firms' competitiveness: a review of the literature
}

Beatrice d'Ippolito

\section{To cite this version:}

Beatrice d'Ippolito. The importance of design for firms' competitiveness: a review of the literature. 2014. hal-00936947

\section{HAL Id: hal-00936947 \\ http://hal.grenoble-em.com/hal-00936947}

Preprint submitted on 28 Jan 2014

HAL is a multi-disciplinary open access archive for the deposit and dissemination of scientific research documents, whether they are published or not. The documents may come from teaching and research institutions in France or abroad, or from public or private research centers.
L'archive ouverte pluridisciplinaire HAL, est destinée au dépôt et à la diffusion de documents scientifiques de niveau recherche, publiés ou non, émanant des établissements d'enseignement et de recherche français ou étrangers, des laboratoires publics ou privés. 


\title{
The importance of design for firms' competitiveness: a review of the literature
}

\author{
Beatrice D'Ippolito*
}

\begin{abstract}
Scholars dedicated increasing attention towards appreciating how design has changed individuals' perception of new products, firms' understanding and formulation of strategy, or other relevant actors' approach to innovation and technology management. By emphasising the importance of design for the definition of consumers' needs, the restructuring of firms' organisational structures and strategies, and the evolution of firms' value creation processes, this review paper identifies relevant research gaps and questions that would benefit from future scholarly attention. In particular, it is suggested that such effort should address the analysis of: how design consumption can help better comprehend consumers' needs; what are the implications of design thinking on the skill sets of design professionals; the organisational structure of firms, including the reconfiguration of other business functions, and their strategy; and whether and how design thinking can shape firms' value creation processes and contribute to the formalisation of design tasks.
\end{abstract}

\section{Keywords}

Design; strategy making; consumers' needs; value creation; literature review; firm competitiveness; research gaps.

* Current Address: 12, rue Pierre Sémard, Grenoble Ecole de Management, 38000 Grenoble, France. Tel: +33 4767060 60. Fax: +33 4767060 99. Email address: beatrice.dippolito@grenoble-em.com. 


\section{Introduction}

It is widely recognised that design is an important factor contributing to firms' success because of its potential to boost their competitiveness (Hertenstein et al., 2013, Roy and Riedel, 1997). However the influential role of design extends beyond the performance of the actors directly involved in the manufacturing of products (e.g., manufacturers, retailers) and pervades different spheres of action of individuals (e.g., consumers, users), organisations (e.g., professional designers, firms), and other types of entities (e.g., nations). For instance, scholars have examined how design has changed individuals' perception of new products (Creusen and Schoormans, 2005, Rothwell and Gardiner, 1983), firms' understanding and formulation of strategy (Gemser and Leenders, 2001, Hertenstein et al., 2005, Roy and Wield, 1986), or governors' policy design (Berger et al., 1989, Wray, 1991). Stating that design has impacted the world around us should then come of no surprise. To draw on some real life examples, one could think of how the iPod has changed our attitude to listen music, the Kindle eReader our attitude to reading, or the recent success registered by Tiffany \& Co's jewelleries (i.e., quarterly increase in sales of 7.5 per cent, November 2013, Financial Times). As the senior luxury goods analyst Mario Ortelli (Bernstein Research) states, "when it comes to watches and jewellery, the value and appeal of a piece can lie as much - if not more - in craftsmanship and expertise as opposed to the superficial design" (Paton, 2013a, b). Thus designers have to create products which not only look good but also create value that can be appreciated by the actors involved (Utterback et al., 2006, Verganti, 2009).

Such widespread interest towards various aspects of design has led to the blossoming of multiple definitions of design, all of which are a testimony of its versatile nature (JohanssonSköldberg et al., 2013, Schön, 1983, Simon, 1969). Although scholars agree on the centrality of design for firms' innovativeness, there is still uncertainty about the channels or mechanisms whereby design exerts its 'power'. Creativity is indeed a major component of design, which translates into a high degree of subjectivity and tacitness, hence the difficulty to measure its actual contribution (Dorst and Cross, 2001, Walsh and Roy, 1983).

This conceptual paper about design in management science tries to address this gap by exploring how design phenomena changed not only firms' strategy making but also the way they interpret and, at the same time, inspire consumer behaviour. This latter effect is further amplified by the establishment of non-technological innovations, that is, those new products the success of which depends on more subjective and intangible factors such as aesthetics or 
symbolic values (Hirschman, 1982, Ravasi and Rindova, 2008). Design is understood as part of a problem-solving activity, beginning with the perception of a gap in a user experience, leading to a plan for a new artefact, and resulting in the production of that artefact. In practical terms, this means that, to better comprehend the role of design in both the development of new products and their commercialisation, a process view would account for the required activities as well as the players involved (along with their specific characteristics) to carry them out (Simon, 1969). Differently from extant innovation and management literature, the current paper proposes a new angle of analysis, that is, how the design 'lens' can help learn about consumers' emotional responses, and how it can push firms to think differently about user needs. It is also argued that these aspects will indirectly affect firms' organisational structure and strategy making along with their value creation processes. The remainder of the paper is structured as follows. Section 2 reviews the various definitions of design available in the literature and specifies how it is understood for the aims of this research. Then Section 3 reviews the innovation literature by illustrating how design influenced firms' ways of thinking about consumers' needs, firms' approach to new product development (NPD) and strategy making, and the overall impact on the mechanisms of value creation at firm level. By building on these contributions, Section 4 discusses emergent research gaps and discusses possible avenues for future research. Final remarks and reference to the limitations of the study will conclude the paper.

\section{Defining design}

The significance of design has been recognised by scholars from different fields such as artificial sciences and engineering (Hevner et al., 2004, March and Smith, 1995, Simon, 1969), innovation and aesthetics (Petroski, 1996, Verganti, 2003, Walsh, 1996), management (Cooper and Press, 1995, Dumas and Mintzberg, 1989, Walsh et al., 1992), and arts and creativity (Olins, 1986, Potts, 2009, Potts and Cunningham, 2008, Sparke, 1986). These bodies of literature highlight how the drivers for innovation that underpin design can range from purely artistic elements to more problem-solving, engineering-based reasoning. This leads to design impinging on different types of knowledge, from the more rational and formalised, thus objective, knowledge of engineering designers to the more expressive and tacit, thus subjective, knowledge of graphic designers. As a result, despite a shared understanding that design is a potential enabler of innovation, the spectrum of meanings acknowledged is still relatively wide. 
How did design come to gain such recognition? Arguably the first design publications date back to Roman times with work by Vitruvius, a roman writer, architect and engineer active in the first century BC and best known for his multi-volume work De Architecture ("On Architecture"). However it was only in the 1960s that major research programmes were initiated by drawing on the systems view and using concepts from operations research (Jones and Thornley, 1963). A desire to 'scientise' design can be traced back to the twentieth century Modern Movement in design, when the protagonists for the movement proactively produced works of art and design based on objectivity and rationality, that is, based on the values of science (Cross, 1993, 2000, Cross et al., 1981). However serious attention towards design being worthy of in-depth, scientific investigation was triggered in the early 1960s by two conferences, one held in London in 1962 and one held in Birmingham in 1965 (Maffei, 2010), both of which raised interesting debates on the need to develop a science of design.

The term 'design science' was officially introduced by Gregory (1966a), who proposed that "design science is concerned with the study, investigation, and accumulation of knowledge about the design process and its constituent operations. It aims to collect, organise, and improve those aspects of thought and information which are available concerning design, and to specify and carry out research in those areas of design which are likely to be of value to practical designers and design organisations" (Gregory, 1966b:123). Herbert Simon's (1969) Sciences of the Artificial is yet the landmark contribution that considers the nature of the disciplines dealing with phenomena as if they were artefacts. As he warns us, "we need a science of design - intellectually tough, analytic, partly formalisable, partly empirical and teachable" (Simon, 1969:xii). It is with Simon's contribution that design develops its first roots in engineering and the sciences of the artificial. Under this perspective, design is a problem-solving activity centred on the definition of the problem, identification and generation of alternative solutions, and evaluation and selection of the most suitable one (Bayazit, 2004, March and Smith, 1995). Generally speaking, in the context of this paper the understanding of design is in line with Simon's information processing view. Design is conceived as part of a problem-solving activity beginning with the perception of a gap in a user experience, leading to a plan for a new artefact, and resulting in the production of that artefact. The artefact can be any result of intentional creation, including physical goods, software, and services. Thus the paper focuses on the consequences triggered by the production and repeated supply of a given artefact (Ulrich, 2011) and how those impact individuals' and firms' behaviours. 
By starting with a reflection on the semantics of the term 'design', Verganti (2003) suggests that its etymology goes back to the Latin 'de + signare' and refers to "making something, distinguishing it by a sign, giving it significance, designating its relation to other things, owners, users or goods" (2003:157). Moreover, 'design' can be a noun or a verb, that is, "a product which has been made by humans may be referred to as 'a design', while the activity that produced this product is the act of 'designing"' (Beltagui et al., 2008:5). Nevertheless, agreeing on one single definition still remains a challenge. Table 1 lists the main definitions of design developed in the literature. By providing an insight on the main tenets, sources of reference, and implications for innovation, the table introduces design as the cumulative development of an initial creative act which builds up its shaping dimension, that is, the ability to assign a meaning to the design object, and then, its applicative dimension, which translates in the artefact playing a more explicit role in firms' strategy making and innovation practices (Ardayfio, 2000).

Table 1 about here

In the sections that follow I illustrate how the evolution of design has influenced the way firms think through consumers' needs and decide about innovation, and how design activities have shaken the relationship between business functions and the processes of value creation at firm level. Examples like the iPod or Kindle recalled earlier teach us not only that consumer tastes have changed, but also that firms have transformed, or been 'forced' to transform, their NPD capabilities through a recombination of existing resources with new, less tangible ones, such as symbols or values.

Scholars have made various attempts to review the design and innovation literature, as Appendix Table 1 illustrates. Whilst each of the reviews recounted in the table highlights specific dimensions of design (e.g., design as a means to resolve problems in a creative way, design as a methodological concept within the information systems and design software literature), in this paper it is proposed a combined view of different strands of literature with the aim of illustrating how the behaviour of individuals and firms can be affected by design. The reviewed literature is included in Appendix Table 2, the structure of which follows the structure and headings of Section 3 below. The table specifies, for each contribution, the following details: the focus of the publication, the keywords provided by the authors (where lacking, these were identified based on the content of the publication), the methodology, the 
field(s) in which the contribution has been published, and the type of source (e.g., book, journal, etc.). The search of literature was qualitative and relied mainly on a snowballing technique, that is, the strategy of selecting a contribution emerged as the study was unfolding (Ravasi and Stigliani, 2012). The focus was on exploring how the strengthening role of design and rising importance of non-technological innovations along the technological ones can shape consumer choices as well as firms' NPD strategies and processes for value creation. This phase was autonomously executed by the author and, in order to avoid personal biases, discussions with field experts and practitioners such as industrial designers, academics from the R\&D management field, and engineering designers followed.

\section{The effects of a changing notion of design: a literature review}

The literature review presented in this section aims exploring how the evolving notion of design has impacted firms' approach to predict and interpret consumers' needs (Section 3.1), firms' internal structure and strategy making (Section 3.2), and the firm-level mechanisms in place for value creation (Section 3.3).

\subsection{Design and the interpretation of consumers' needs}

Within modern economies the value of products is increasingly associated with both their functionality and style: while functionality is expressed by technology, style refers to the aesthetic form and/or symbolic value of new products (Hirschman, 1982, Ravasi and Rindova, 2008). Style is an increasingly relevant phenomenon in many industries even outside creative industries (Cappetta et al., 2006); and stylistic elements are those which could be substituted without diminishing the functionality of a product in a purely technical sense (Wijnberg, 2004:1420).

Firms have become aware that design, and product appearance more specifically, not only contributes to determine the aesthetics and functionalities of new products but can also influence consumption choices and trigger new needs or types of needs (Creusen and Schoormans, 2005, Rothwell and Gardiner, 1983). Put otherwise, different appearances can be made for groups of consumers that differ in terms of product value that is most important for their choice. To draw on an example given by Creusen and Schoormans (2005), people who need glasses may prefer an alarm clock with buttons that have a bright contrasting colour as opposed to the casing, so they can locate the buttons better in a dark room. Other people may dismiss such a product on aesthetic grounds (2005:78). Design is not only about 
the invisible linkages among internal components and how these affect the form of the product such as size or weight (Clark, 1985), but also about aspects that are visible or perceptible by the senses such as colour, shape, texture, or sound emitted (Eisenman, 2012). Moreover the growing prominence of design has been inextricably associated with the "transformation of consumer desires" (De Vries, 2008), which has triggered an emotional response on the consumer side. This coincides with the emergence of a new consumer identity, one in which households have an active role and engage in consumption as a discovery process (Bianchi, 2002, Veryzer, 2000). Emotional responses can in turn incite consumers to select a particular product from a row of similar items, a mechanism that firms have found generating an impact on purchase decisions (Wrigley, 2011).

In the broader remit of firms' innovation processes, accounting for consumers' emotional response is important for co-creating added value (Füller, 2010, Lehrer et al., 2012, Witell et al., 2011), that is, for generating meaningful appearance and symbolic value (Di Maria and Finotto, 2008, Esbjerg and Bech-Larsen, 2009), elements at the core of non-technological innovations. Whilst this relationship should be managed by firms, Tran (2010) remarks that asking consumers what they want or involving them in the innovation process can lead to outdated product innovation.

In the context of product design and development, prototypes intended as the first visible expression of designers' creativity (Gero, 1990) are used to create value. In general, the use of prototypes throughout the design process provides rich opportunities for individuals to take a physically active approach to learning and experimentation (Jones and Jordan, 1998, Leonard and Sensiper, 1998). From this perspective prototyping represents an important design practice and, as such, a central element in corporate innovation processes (Bogers and Horst, 2013, Leonard and Rayport, 1997). Whilst firms already use prototypes to gather external feedback in industries where design conveys symbolic know-how (for instance, home furnishing manufacturers 'test' their prototypes during exhibitions and fairs, D' Ippolito et al., 2013), in other industries prototypes mainly constitute the artefact based on which within-the-firm interactions allow the initial concept to mature (Tovey et al., 2003, Yang, 2009). With the aim of understanding how prototyping can support design practices, Bogers and Horst (2013) have investigated how collaborative prototyping could improve product usability and usefulness. The authors have found that prototyping translates usability problems into design changes and detects emerging usability problems through active engagement and experimentation. Thus, the authors argue, it is possible to distinguish 
between a bureaucratic phase of prototyping, of managerial nature, and a conceptual one, strictly connected with design. It is in this latter stage that the act of prototyping is transformed from an activity belonging exclusively to design engineers to an activity integral to NPD, with participants from within the organisation - different functions and managers and from outside - consultants and users (Bogers and Horst, 2013).

These recent developments on the role of prototyping in fostering communication and triggering a response from consumers as well as the rising importance of non-technological innovations portray a richer view of design. By bringing together different traditions within the design literature, we learnt how design influences consumers' desires and shapes their choices, for instance by creating new symbolic values, but also how firms react to these responses, for instance by exploiting the experimental potential of prototypes. More research is yet needed with regard to how firms combine traditional technological capabilities with abilities to create symbolic value (Tran, 2010).

\subsection{Firms' reorganisation: (re-)empowering other business functions}

The changes described above have undoubtedly influenced the way designers apply problemsolving techniques and combine them with NPD-related activities within the broader domain of firms' organisational structures. Besides acknowledging the importance of technical knowledge (e.g., principles, methodologies), designers rely on personal skills and experience, which can remain tacit in nature or instead be codified and implemented through procedures or manuals (Petroski, 1996, Utterback et al., 2006, Vincenti, 1990). As a result of these trends, firms have started to appreciate the potentials of design and shape their organisational activities such as brand development or strategy implementation accordingly. I suggest that, in order to support both technological and non-technological innovations, a different approach to strategy- and decision-making is required, one that leads to the redefinition of roles both within and beyond organisational boundaries (Walsh, 1996, Walsh and Roy, 1983). The subsections below unveil how design has altered firms' organisational structures (Section 3.2.1) and the implementation of strategy (Section 3.2.2).

\subsubsection{Design and firms' organisational structure}

In a similar fashion to other business activities, the practical implementation of design within the matrix of firms' activities entails three options: outsourcing, in-house development, or a combination of the two (Abecassis-Moedas and Benghozi, 2012, von Stamm, 1997, 2008). Whilst there are barriers to use external designers because of the high costs involved, there is 
no vade mecum as to where design activities should be best located, either within or beyond organisational boundaries. In some firms the designer is also the firm's art director and contributes significantly to the firm's strategy; in other cases professional designers are only one piece of the puzzle among all the others (Ulrich and Eppinger, 1995). Partly due to the creative and implicit nature of design, organisations may also fail to appreciate its value and, instead of considering it as a keystone of the product development process, they mainly associate it with aesthetics or styling.

Notwithstanding these options, existing research into design management, both of theoretical nature (Bruce and Morris, 1994, Dumas and Mintzberg, 1989, Walsh, 1996) and empirical nature (Ahire and Dreyfus, 2000, Bruce et al., 1999, Dickson et al., 1995, Perks et al., 2005, Roy and Riedel, 1997), has yet not fulfilled the attempts to define the identity of design within organisations. Dumas and Whitfield (1989) conducted one of the former studies regarding what firms think about design, where it is located, and how it should be managed. Whilst the authors were able to distinguish between four types of firms depending on their approach to design and the role of the design manager in decision making, their results were equivocal with regard to what constitutes design, who is responsible for design, whose budget finances design, the availability and coverage of design guidelines, and the power of design managers (Dumas and Whitfield, 1989). Thus, unlike the case of technology developments, design developments (i.e., partly not driven by technological developments) are not clear-cut and companies struggle to manage them.

Some scholars have attributed this struggle to the difficulty of managing the relationship between manufacturers and professional designers (Dell'Era and Verganti, 2010, Ravasi and Lojacono, 2005, Ravasi et al., 2008). Filippetti (2010) emphasised that very often designers are located outside the firm, a condition that raises a central management issue for the firm. In his paper, he argues that there is an 'essential tension' between the two parties, and an important determinant of a successful collaboration lies in the designer's deep understanding of the firm's features such as production processes, innovation strategy, branding, and communication approach. The author found that external designers are an important source of competitive advantage, for instance via new ideas, and managing the tension is essential for developing a long-term, sustainable advantage. However in Filippetti (2010) little attention is given to the extent to which a firm's technical expertise adapts to, or is shaped by, the collaborations with designers. 
Some interesting insights could be found in Perks et al. (2005), who explored the role of design within the NPD process of mid-size to large UK manufacturing companies and identified three potential roles design can play:

a) design as a functional specialism: designers in this category concentrate purely on design; their basic tasks consist of receiving the brief and carrying out sufficient research to inform their own design. The skill set developed to this aim centres on the traditional design skills, which include aesthetics, visualisation, and technical skills;

b) design as part of a multifunctional team: a team approach is used throughout the development process. With design being identified as a crucial aspect of product development, designers emerge as key players in the team; they are encouraged to support other functions, for instance by participating to in-house reliability testing;

c) design as NPD process leader and a major force for innovation: designers drive and support actions throughout the entire development process and across a broad scope of functional activities (Perks et al., 2005).

In each of these categories, the role of the designer varies according to the managerial choices involved: in scenario ' $a$ ' the designer is mainly engaged with the aesthetic aspects of NPD; in scenario ' $b$ ' the designer participates in NPD-related decision making along with other experts; and in scenario 'c' the designer is the leader of the NPD process. The position of the designer within the firm will vary accordingly: independent professional in 'a', member of the product development team in 'b', and a cross-functional player in 'c'.

This perspective of analysis complements previous studies that explored the relationships between designers' experience and attitudes to working in a cross-functional team and their creativity. Fisher (1997) argued that, depending on the level of creativity of individual professionals, their role can vary from a more romantic stereotype of the creative genius to one that considers creativity as an attribute possessed by all human beings in some measure, which can be enhanced by personal effort or training. More recently, Li et al. (2007) presented a qualitative model of creativity for product innovation by integrating principles from cognitive psychology, information technologies, and design theories. Their model identifies those aspects of creativity that are relevant in creative design, including thinking styles, knowledge, information, design methods, and supporting tools. What is missing in these studies is a deeper understanding of how firms can capture the tacit component of design and use it to improve existing practices or shape strategy. Chiva and Alegre (2007) 
conducted a survey in the Spanish and Italian ceramic tile industry which explored the fit between design management skills and design function organisation. Their results revealed that companies have different degrees of design management skills depending on how the design function is organised: those firms relying solely on in-house design appear to be the most skilled firms. I believe it is important to pursue further this research directory in order to better understand how design activities can modify the configuration of firms when both technological and non-technological developments are at stake.

\subsubsection{Design and the strategy of the firm}

In making one step further in the literature review, I would like to draw attention to the strong, mutual relationship between firms' strategic decisions and the environment in which they operate, and between the types of product and process innovations and the capabilities deployed in support of such innovations (Utterback and Abernathy, 1975).

Design emerges as an important component of firms' strategic approach and competitiveness since it allows the synthesis and integration of external knowledge with firms' organisational capabilities. Major empirical studies dating back to the 1970s and 1980s illustrated how the integration of specialised activities such as design and manufacturing constitutes an essential element of innovation success (Cooper and Kleinschmidt, 1987, Gardiner and Rothwell, 1985, Johne and Snelson, 1988). Scholars' attention began with a focus on how design can influence firms' decision making and their efforts to build a competitive advantage. Gorb and Dumas (1987) and Borja de Mozota (1990) regarded design as strictly intertwined with firms' management concern. In reality, this attitude dates back to earlier research that focused on the importance of design as a strategic process which seeks to optimise consumer satisfaction and company profitability via different levers such as improved performance, form, durability, and value in connection with products, environments, or identities (Kotler and Rath, 1984). They suggested that satisfactory results can be achieved by training general managers, marketers, and engineers about the content and value of design, and designers about the ways of interacting with other actors within the firm.

Verganti (2003) illustrated the central role designers play within organisations that have grounded strategies on radical design-driven innovations. In referring to a practical example such as the 'Metamorfosi' lamp by Artemide, the author suggested that firms should research new languages (e.g., brainstorming ideas in workshops attended by the firm's CEO and managing director for brand strategy, five well-known designers and a design professor), new 
technologies (e.g., by exploiting new applications of lighting technology), and NPDs (e.g., by combining the new meanings with the new technologies). In more general terms, Verganti proposed that firms should build their competitive advantage by strengthening and exploiting their network of long-term relationships with brokers of languages alongside the set of channels used to guarantee access to specialised knowledge (Verganti, 2003). By broadening the angle of analysis and aiming to contribute extant innovation management literature, Verganti (2008) proposed the use of a metamodel for the investigation of design-driven innovations. In it, manufacturers' ability to understand, anticipate, and contribute to the emergence of new product meanings is built by relying on external interpreters such as designers, suppliers, schools, artists, and the media; the interaction with these interpreters is essential to access, share, and internalise knowledge on product languages and to model shifts in socio-cultural settings.

The above arguments suggest that design is relevant not only at the product level through a direct impact on product architecture, but also at the organisational level through the influence on strategy making (Brown, 2008, Cross, 2011). The question to ask is: what are the consequences for strategy when design thinking is involved? Existing literature has highlighted how firms have increased their collaboration with design professionals early on in the NPD process. Design management scholars have for instance explored how design activities are integrated in practice with innovation and strategy-building (Gemser and Leenders, 2001, Perks et al., 2005). Nevertheless, it is yet unclear how the interaction with designers throughout the NPD process would change in a context where non-technological factors have gained consensus and whether this can re-empower other, more peripheral business functions such as production or communication.

\subsection{Design and the value creation processes of the firm}

The previous subsections have illustrated how design, by influencing both strategy making and the interpretation of consumers' needs, can facilitate the integration of new ideas across the organisation, thus increasing efficiency and reducing time to market (Black and Baker, 1987, Fujimoto, 1990). Firms are increasingly 'pressured' to engage with concepts such as design thinking or design-driven innovation (Brown, 2008, Johansson-Sköldberg et al., 2013, Lee and Evans, 2012, Razzouk and Shute, 2012). The literature reviewed in this subsection does not encompass the contributions to organisational studies that explore how design-led reasoning can be exploited to build firms' business models (Pandza and Thorpe, 2010, 
Romme, 2003, Zott and Amit, 2007, 2010). Although relevant, they do not fall within the scope of this review, that is, to question how design can help firms generate added value. Scholars have in fact highlighted the importance of design for innovation (Filippetti, 2011) and, because of its role in product differentiation, its contribution to firms' competitiveness (Chiva and Alegre, 2009, Trueman and Jobber, 1998).

The business model literature provides an interesting insight on these aspects. Whilst business models have initially been conceived as locus of innovation and crucial source of value creation for the firm and its stakeholders (Teece, 2010, Zott et al., 2011), the increasing complexity of organisational strategies has contributed to the establishment of business model portfolios, that is, sets of different activities firms undertake to meet consumers' needs and build idiosyncrasy among these activities (Sabatier et al., 2010). This concept highlights the specific combination of resources required to deliver value propositions. Baden-Fuller and Mangematin (2013) have further argued that seeing business models as potentially alterable configurations can help managers think about how to act in future states of the world and, at the same time, assist researchers in developing new theories.

Earlier works within the design and innovation literature exploring the impact of design on firm' success encompass the results of a project entitled 'Market Demands that Reward Investment in Design' brought to light by Roy and Riedel (1997). The authors argued that in commercial successful product development projects more attention has been paid than in the loss-making projects to genuine product improvements rather than just styling or cost reduction. They also found that commercially successful product development projects drew upon a multidimensional approach to design with a focus on product performance, features and quality and, where appropriate, technical or design innovation (Roy and Riedel, 1997). Another major initiative dating back to the 1980s and aiming at the promotion and evaluation of the use of professional design expertise in small and medium-sized firms across the UK has been the Funded Consultancy Scheme / Support for Design (FCS/SFD) programme, launched by the British Government, and which led to numerous reports and academic journal articles (Roy and Potter, 1990, Roy et al., 1986, Walsh et al., 1992). More recent scholarly efforts have focused on the assessment of the extent to which design can contribute to companies' financial performance (Candi, 2006, Filippetti, 2011, Hertenstein et al., 2005, Moultrie and Livesey, 2013).

In general, consensus can be found that product design impinges on price and non-price factors such as product performance, ease of use, durability, and product delivery. This 
argument strengthens the point made in the previous section, according to which design has the potential of bringing into the picture some non-technological dimensions of new products that firms had not considered before (see for instance Candi and Saemundsson, 2011, for an exploration of how the use of aesthetic design as an element of new service development is likely to improve firm performance).

Implicit in this discussion is that design influences not only products but also the set of mechanisms through which firms generate added value. Because of the strict bond between design (as determining the aesthetics of new products) and firm identity (as deriving from firms' willingness to develop a given status or style), it is very likely that the role of design in shaping a firm's business model is mostly influential during the value creation phase, that is, when the user target(s) is(are) identified and the product features defined. Ideally, firms would seize the added value deriving from the optimisation of the production costs associated to design products manufacturing via an overcharge on consumers. In reality only few firms can benefit from this privileged position (e.g., Alessi in the home furnishing industry, or Apple in the consumer electronics and computer industries), whereas in the remaining cases the ultimate scope of design is that of continuously reinforcing synergy among products and, in turn, among the elements of firms' business model portfolios. Put otherwise, by challenging the existing business model of the firm, design mediates between technology development and economic value creation (Bohnsack et al., 2014, Chesbrough, 2010, Chesbrough and Rosenbloom, 2002).

Design is situated in a given setting and context, and meanings are not a mere backdrop but important and integral factors central to comprehending how actors develop ideas or objects, and exploit them within built environments. Moreover, similarly to other creative activities, design is a social phenomenon: it impacts behaviours (Bianchi, 2002), it relies on social interactions as the source for feedback (Petroski, 1985, Vincenti, 1990), and it creates new ways of perceiving the social settings (Caves, 2002, McLeod et al., 2009).

The above literature review sought to illustrate how design has influenced the way firms think of consumers' needs, how the raising importance of design has empowered not only the NPD function but also other business units, and how design investments can shape the formation of mechanisms apt to generate added value. The evolution of the concept of design has represented an expansion of the original remit from the science of design to its 
professionalisation, then to its evaluation; indirectly, for each accomplished step, new sets of knowledge have facilitated the adaptation of the meaning of design to new contexts. Interestingly, as it is possible to observe from Appendix Table 2, the background of the scholars contributing to the development of the design literature is rather diversified, not only engineering or product design, but also marketing, management, policy, and science (Gregor, 2009), once again, sign of the pervasiveness of design activities across various domains.

\section{Gaps in the literature and future research avenues}

It is the aim of this section to follow up with the discussion of emergent gaps in the literature. Whilst not meant to be normative or all-encompassing, the intent is to draw attention to some aspects that would benefit from future scholarly attention.

\subsection{Design and a better understanding of demand}

Existing literature draws attention to how non-technological innovations have impacted our understanding of design, by envisioning its potential to predict consumer preferences (e.g., use of design prototypes for value co-creation) or the role customers themselves play in the definition of new product features. To date most effort has been placed on understanding how a product or process innovation should be conducted by the actors involved, without specifying whether it is a team or an individual effort, that is, "who should do what' (e.g., designers, engineers, or consumers).

Addressing these questions would shed light on different aspects related to the changing nature of design. First, in further developing the science of design, research efforts could focus on the role played by design professionals within the NPD process. For instance, by exploring their interaction with other actors, it would be possible to learn about the sources of knowledge on which creative individuals formulate new meanings or products. The knowledge perspective, in turn, opens another relevant stream of research which concerns the skills needed for undertaking design activities in an effective way. Designers need to rely on expertise that does not lend itself to easy theorising, tabulation, or programming into a computer. A significant part of the know-how is acquired on the job rather than in school or from books, and tends to remain tacit (Petroski, 1994, Vincenti, 1990). Because of this individual creative component, a full understanding of the cognitive foundations underpinning design activities has not been achieved yet. Existing research has relied mainly on narratives or qualitative case studies describing the creative process behind NPD. Future 
efforts could be addressed towards combining qualitative and quantitative research methods in order to capture the cognitive dimension of the interaction as well as the typologies of information exchanged and output.

Second, as argued in Section 3.1, design shapes consumption choices by triggering an emotional response from the consumers and, at the same time, it is inspired by their response for the creation of new symbols or values. The role of demand in the analysis of design has been debated by innovation scholars in various instances and from various perspectives (see Witt, 2001), yet contributions are still very scant. For instance, via which routes does demand influence design? There could be cognitive routes (e.g., changing of professional and graduate programmes), organisational routes (e.g., implementation of mechanisms to gather feedback at the level of the project, business unit, or organisation), or institutional ones (e.g., creation of events fostering the interaction between product developers and consumers). The review of the literature has highlighted experimentation, and in particular prototyping, as the route currently pursued by designers and product developers to fulfil these aims. Prototypes trigger consumers' reactions as well as help engage with them during the process of value creation. It is hereby suggested that prototyping may help customers express their needs in earlier phases of the NPD process; questions such as 'How do consumers learn from interacting with the prototype?' or 'What type of emotional response can the prototype trigger?' are worthy been further explored. With the growing interest in open innovation (Chesbrough et al., 2006, Chesbrough, 2003), mechanisms such as crowdsourcing (Poetz and Schreier, 2012) or social media (Kietzmann et al., 2011) have been adopted by firms to leverage the input coming from different types of consumers. As West and Bogers (2014) suggest, these trends have important implications for both management education and the role of users as innovators. Due to the recent scholarly attention to these issues, an exploratory perspective to the analysis based on mixed research methods would be suggested.

\subsection{Design and firms' structure and strategy}

With the progressive establishment of design as an important component of one or more phases of the NPD process, firms have dealt mainly with three issues: how to manage the value generated by design activities, where to source the specialised expertise and manage it in an organisational context (i.e., outsourcing versus in-house), and how to exploit design for strategic purposes (Le Masson et al., 2011). This subsection explores some unanswered 
questions concerning the organisation of design activities within firms, the way these influence the specialisation of firms, and finally, the impact on firms' strategy making.

With regard to the organisation of design activities, the literature review has emphasised how, while design does not have a 'business identity' of its own (yet?), it appears to significantly affect firms' competitiveness in terms of strategic positioning, innovativeness, and financial performance. Because of this pervasiveness, I suggest that future research should extend the focus towards assessing the benefits attached to the deployment of design capabilities (Fernández-Mesa et al., 2013, Ravasi and Stigliani, 2012), and investigating how the formalisation of design activities can shape the configuration of other business functions or decision making regarding the NPD process (Perks, 2007). Scholars have discussed the delicate 'relationship' between design and marketing (Beverland, 2005, Cooper and Kleinschmidt, 1987, Moenaert and Souder, 1990, Veryzer, 2005) or manufacturing (Gardiner and Rothwell, 1985, Johne and Snelson, 1988, Twigg, 1998, 2002), but very little is known about whether, and if so how, design as a service and creative activity impacts the configuration or function of other business units (Cooper et al., 2009). In order to shed light on how the development of design knowledge shapes the activities of other business functions, it is hereby suggested that qualitative research could extend our understanding of the nature of design-related skills and competencies and their relation with firms' existing competencies.

Because of the multi-disciplinarity of design and its proven relevance for firm competitiveness, the way it is coordinated has some effects on the overall organisation of the firm and its specialisation. I argue however that we know very little about these aspects. Bruce et al. (1995) identified management skills as being essential for the exploitation of design expertise, that is, preparation of design briefs, regular communication between the marketing, design and production departments, and effective project management. Exceptions aside, the set and nature of desirable competencies for a designer still represent largely unexplored areas within the innovation literature. Thus, at the individual level, it would be relevant to investigate what types of skills designers should possess, besides a creative soul; at the organisational level, it would be sensible to explore to what extent designers can establish themselves as professionals within the firm, and what would be the deriving implications on strategy.

The increasing pervasiveness of design across firms' organisational structure has led, over time, to the alignment of their strategies with design principles, that is, with the embodiment 
of design-oriented thinking in the formulation and implementation of strategy. Scholars have already examined how design thinking can shape new product developments, as explored in Section 3.2. Here it is suggested that further attention should be given towards other elements or actors which, while involved with the development of new products, have the potential to influence strategy making. For instance, how does the role of the art director as the 'guarantor' of a coherent and consistent new product strategy contribute to the formulation of innovation strategies? Or what role the materials expert has in determining firms' medium- to long-term NPD-related choices? Scholars have highlighted the need for more research on the language of designers and managers (Micheli et al., 2012), thus future research may focus on assessing how the assimilation of design principles within firms' credo can guide their patterns of specialisation. Quantitative studies could build on the constructs developed within the strategic and innovation management literature with the aim of testing existing indicators or broadening their scope.

\subsection{Design and the changing mechanisms for value creation within firms}

Section 3.3 has explored extant literature regarding design as an important contributor to organisational success not only because it is influential throughout the NPD process but also because it affects the mechanisms of value creation at firm level. The review has also brought to the fore the value of supporting the development and implementation of strategy with design reasoning (Martin, 2009). Given the diffusion of non-technological types of innovation, and not very explicit relationship between technological innovations and design (Khaire, 2012), it would be interesting to investigate the role of design on the mechanisms of value creation within these contexts.

The review has also drawn attention to how firm performance and design are positively correlated, yet the debate as to what types of indicators could help assess the impact of design on firm performance is still open. Torbett et al. (2001) explored whether, and if so how, consulting engineering firms have developed design performance measurement practices, and the difficulties firms were confronted with. The authors found that financial indicators were the most widely used means to assess the effectiveness of design initiatives, but could not, on their own, provide sufficient information about design quality (Torbett et al., 2001). It is hereby suggested that future efforts may explore under which circumstances firms select certain design solutions, and what are the deriving consequences. With the increasing importance of consumers, financial indicators of the kind described above may be integrated, 
for instance, with a measure of customer satisfaction, or the extent to which the design element in a product affects future customers' consumption choices. Qualitative research methods could help gain understanding of how and why consumers perceive a specific design and, based on these findings, simulations or scenario building could provide a deeper analysis of consumer behaviour.

The story recounted here reflects a change in the business models of firms, in particular how design has shaped the definition of new product features and, in turn, the mechanisms of value generation with the introduction of new products. Nevertheless, it is still difficult to investigate how, design-intensive firms have been affected by the characteristics of the industry within which they operate. One of the reasons lies in the struggle to classify design in the realm of industrial activities such as the NACE coding system, but it is also due to the lack of scholarly attention towards the institutional mechanisms through which design activities and design professionals gain legitimacy. One could for instance speculate about the role of individual designers as innovator or the role of design as a potential policy tool. Efforts have been made towards applying design principles to the design of policies and control of economic growth, but less to exploiting how design can trigger business model innovation (Brunswicker et al., 2013). This, I believe, is a path worth investigating in the future, by means of qualitative and quantitative approaches focusing on either the firm or the country.

\section{Concluding remarks}

This conceptual paper has highlighted how design has influenced individuals' behaviours and firms' decision making with regard to new product design and development. By emphasising the importance of design for the definition of consumers' needs, the restructuring of firms' organisational structures and strategies, and the evolution of their business models, the paper has identified different research gaps and questions that would benefit from future investigation. In particular it has been suggested that future analyses may examine the following aspects: (i) how design consumption can help better comprehend consumers' needs; (ii) what are the implications of design thinking on the skill sets of design professionals; (iii) the organisational structure of firms, including the reconfiguration of other business functions, and their strategy; and (iv) whether, and if so in which terms, design thinking can shape firms' value creation processes and contribute to the formalisation of design tasks. 
As portrayed throughout the paper, the relative wide range of definitions renders the task of defining design in a univocal way a difficult one. However I hope to have contributed innovation studies by proposing a new perspective to the reading of the design literature and identifying relevant research avenues for future exploration. The diversity of fields in which the listed contributions were published seems to suggest, and confirm, the pervasiveness of design across various spheres of action of individuals, firms, and other entities. It would thus be interesting to observe how research work in these domains will affect and be affected by design research in the near future.

Some reflections on the limitations of the research must be admitted. First, the arguments presented above seem to prioritise the organisational and strategic dimensions attached to design by downplaying some other, similarly important dimensions. To partly reduce this effect, some references and connections to other facets of design were made throughout the manuscript (e.g., design as a profession, design as an economic activity). Second, given the qualitative approach adopted for the literature search, room for future, in-depth explorations of the raised issues should be allowed.

\section{Acknowledgements}

I am indebted to Marcela Miozzo, Davide Consoli, Stan Metcalfe, Davide Ravasi, Jon Johnson and Rob Reitsma for insightful comments on previous versions of the manuscript. The thought-provoking comments of two referees and of the editor were crucial to improve the manuscript substantially. A preliminary draft was presented at the R\&D Management Conference 2012, in which occasion I benefited from comments by Sarah Lubik. I acknowledge financial support from the British Economic and Social Research Council (ES/F022735/1) and the Università Cattolica del Sacro Cuore (Piacenza, Italy). The opinions expressed in this paper are those of the author. The usual caveats apply. 


\section{References}

Abecassis-Moedas, C., Benghozi, P.-J. 2012. Efficiency and innovativeness as determinants of design architecture choices. Journal of Product Innovation Management. 29, 405-418.

Ahire, S. L., Dreyfus, P. 2000. The impact of design management and process management on quality: an empirical investigation. Journal of Operations Management. 18, 549-575.

Ardayfio, D. D. 2000. Principles and practices of design innovation. Technological Forecasting and Social Change. 64, 155-169.

Baden-Fuller, C., Mangematin, V. 2013. Business models: a challenging agenda. Strategic Organization. 11, 418-427.

Bayazit, N. 2004. Investigating design: a review of forty years of design research. Design Issues. 20, 16-29.

Beltagui, A., Riedel, J., Livesey, F., Demian, P., Moultrie, J. 2008. Briefing note 1: What is design? A review of definitions. DesignScoreboard - A novel approach to measuring the UK's National Design Performance. 1-19.

Berger, S., Dertouzos, M. L., Lester, R. K., Solow, R. M., Thurow, L. C. 1989. Toward a new industrial America. Scientific American. 260, 21-29.

Beverland, M. B. 2005. Managing the design innovation-brand marketing interface: resolving the tension between artistic creation and commercial imperatives. Journal of Product Innovation Management. 22, 193-207.

Bianchi, M. 2002. Novelty, preferences, and fashion: when goods are unsettling. Journal of Economic Behavior and Organization. 47, 1-18.

Black, C. D., Baker, M. J. 1987. Success through design. Design Studies. 8, 207-216.

Bloch, P. H. 1995. Seeking the ideal form: product design and consumer response. Journal of Marketing. 59, 16-29.

Bogers, M., Horst, W. 2013. Collaborative prototyping: cross-fertilization of knowledge in prototype-driven problem solving. Journal of Product Innovation Management. 31, 1-21.

Bohnsack, R., Pinkse, J., Kolk, A. 2014. Business models for sustainable technologies: Exploring business model evolution in the case of electric vehicles. Research Policy. 43, 284-300.

Borja de Mozota, B. 1990. Design as a strategic management tool, in: Oakley, M. (Ed.) Design Management: A Handbook of Issues and Methods. Blackwell, Oxford, pp. 73-84.

Bousbaci, R. 2008. "Models of man" in design thinking: the "bounded rationality" episode. Design Issues. 24, 38-52.

Brown, T. 2008. Design thinking. Harvard Business Review. 86, 1-9.

Bruce, M., Cooper, R., Vazquez, D. 1999. Effective design management for small businesses. Design Studies. 20, 297-315.

Bruce, M., Morris, B. 1994. Managing external design professionals in the product development process. Technovation. 14, 585-599.

Bruce, M., Potter, S., Roy, R. 1995. The risks and rewards of design investment. Journal of Marketing Management. 11, 403-417.

Brunswicker, S., Wrigley, C. J., Bucolo, S. 2013. Business model experimentation: what is the role of design-led prototyping in developing novel business models, in: Curley, M. and Formica, P. (Eds.), The Experimental Nature of New Venture Creation. Springer International Publishing, Switzerland, pp. 139-151.

Buchanan, R. 1992. Wicked problems in design thinking. Design Issues. 8, 5-21. 
Candi, M. 2006. Design as an element of innovation: evaluating design emphasis in technology-based firms. International Journal of Innovation Management. 10, 351-374.

Candi, M., Saemundsson, R. J. 2011. Exploring the relationship between aesthetic design as an element of new service development and performance. Journal of Product Innovation Management. 28, 536-557.

Cappetta, R., Cillo, P., Ponti, A. 2006. Convergent designs in fine fashion: an evolutionary model for stylistic innovation. Research Policy. 35, 1273-1290.

Caves, R. E. 2002. Creative industries, Harvard University Press, Cambridge, Massachusetts.

Chesbrough, H. 2010. Business model innovation: opportunities and barriers. Long Range Planning. 43, 354-363.

Chesbrough, H., Vanhaverbeke, W., West, J. 2006. Open Innovation: Researching a New Paradigm, Oxford University Press, Oxford.

Chesbrough, H. W. 2003. The era of open innovation. MIT Sloan Management Review. 44, $35-42$.

Chesbrough, H. W., Rosenbloom, R. S. 2002. The role of the business model in capturing value from innovation: evidence from Xerox Corporation's technology spin-off companies. Industrial and Corporate Change. 11, 529-555.

Chiva, R., Alegre, J. 2007. Linking design management skills and design function organization: an empirical study of Spanish and Italian ceramic tile producers. Technovation. 27, 616-627.

Chiva, R., Alegre, J. 2009. Investment in design and firm performance: the mediating role of design management. Journal of Product Innovation Management. 26, 424-440.

Clark, K. B. 1985. The interaction of design hierarchies and market concepts in technological evolution. Research Policy. 14, 235-251.

Cooper, R., Evans, M., Williams, A. 2009. The future of the UK design industry - An investigation into the threats and opportunities for the UK design industry over the next 10 to 15 years. Design 2020. 1-52.

Cooper, R. G., Kleinschmidt, E. J. 1987. Success factors in product innovation. Industrial Marketing Management. 16, 215-223.

Cooper, R. G., Kleinschmidt, E. J. 1995. Benchmarking the firm's critical success factors in new product development. Journal of Product Innovation Management. 12, 374-391.

Cooper, R. G., Press, M. 1995. The design agenda. A guide to successful design management, Wiley, Chichester.

Creusen, M. E. H., Schoormans, J. P. L. 2005. The different roles of product appearance in consumer choice. Journal of Product Innovation Management. 22, 63-81.

Cross, N. 1993. Science and design methodology: a review. Research in Engineering Design. 5, 63-69.

Cross, N. 1997. Descriptive models of creative design: application to an example. Design Studies. 18, 427-440.

Cross, N. 2000. Design as a discipline, in: Proceedings of Doctoral Education in Design: Foundations for the Future, International Conference, La Clusaz France 9-12 July, 2000 France. Staffordshire University Press.

Cross, N. 2006. Designerly ways of knowing, Springer-Verlag, London.

Cross, N. 2011. Design Thinking: Understanding How Designers Think And Work, Berg, Oxford. 
Cross, N., Naughton, J., Walker, D. 1981. Design method and scientific method. Design Studies. 2, 195-201.

D’Ippolito, B., Miozzo, M., Consoli, D. 2013. Knowledge systematisation and the development of a business function: the case of design. Danish Research Unit for Industrial Dynamics (DRUID) Working Paper No. 13-06. pp. 1-41. (available at: http://www3.druid.dk/wp/20130006.pdf).

De Vries, J. 2008. The Industrious Revolution: Consumer Behavior and the Household Economy, 1650 to the present, Cambridge University Press, New York.

Dell'Era, C., Marchesi, A., Verganti, R. 2010. Mastering technologies in design-driven innovation. Research Technology Management. 53, 12-23.

Dell'Era, C., Verganti, R. 2010. Collaborative strategies in design-intensive industries: knowledge diversity and innovation. Long Range Planning. 43, 123-141.

Di Maria, E., Finotto, V. 2008. Communities of consumption and Made in Italy. Industry and Innovation. 15, 115-123.

Dickson, P., Schneier, W., Lawrence, P., Hytry, R. 1995. Managing design in small highgrowth companies. Journal of Product Innovation Management. 12, 406-414.

Dorst, K. 1996. Describing Design: A Comparison of Paradigms, Delft Institute of Technology, Delft.

Dorst, K., Cross, N. 2001. Creativity in the design process: co-evolution of problem-solution. Design Studies. 22, 425-437.

Dumas, A., Mintzberg, H. 1989. Managing design / Designing management. Design Management Journal. 1, 37-43.

Dumas, A., Whitfield, A. 1989. Why design is difficult to manage: a survey of attitudes and practices in British industry. European Management Journal. 7, 50-56.

Eisenman, M. 2012. Understanding aesthetic innovation in the context of technological evolution. Academy of Management Review. 38, 332-351.

Esbjerg, L., Bech-Larsen 2009. The brand architecture of grocery retailers: setting material and symbolic boundaries for consumer choice. Journal of Retailing and Consumer Services. 16, 414-423.

Fernández-Mesa, A., Alegre-Vidal, J., Chiva-Gómez, R., Gutiérrez-Gracia, A. 2013. Design management capability and product innovation in SMEs. Management Decision. 51, 1-30.

Filippetti, A. 2010. Harnessing the 'essential tension' of design: the complex relationship between the firm and designer consultant, in: Series, W. P. (Ed.). Munich: MPRA Munich Personal RePEc Archive.

Filippetti, A. 2011. Innovation modes and design as a source of innovation: a firm-level analysis. European Journal of Innovation Management. 14, 5-26.

Fisher, T. 1997. The designer's self-identity - Myths of creativity and the management of teams. Creativity and Innovation Management. 6, 10-18.

Fujimoto, T. 1990. Growth of International Competition and the Importance of Effective Product Development Management and the Role of Design. Product Strategies for the '90s, in: Conference Proceedings, 1990 London. The Financial Times.

Füller, J. 2010. Refining virtual co-creation from a consumer perspective. California Management Review. 52, 98-122.

Gardiner, P., Rothwell, R. 1985. Innovation: a study of the problems and benefits of product innovation, Design Council, London. 
Gemser, G., Leenders, M. A. 2001. How integrating industrial design in the product development process impacts on company performance. Journal of Product Innovation Management. 18, 28-38.

Gero, J. S. 1990. Design prototypes: a knowledge representation schema for design. AI Magazine. 11, 26-36.

Gorb, P., Dumas, A. 1987. Silent design. Design Studies. 8, 150-156.

Gregor, S. 2009. Building theory in the sciences of the artificial, in: Proceedings of the Fourth International Conference on Design Science Research in Information Systems and Technology (DESRIST 2009), May 7-8 2009 Malvern, PA. pp. 1-10.

Gregory, S. A. 1966a. The design method, Butterworth, London.

Gregory, S. A. 1966b. Design science, in: Gregory, S. A. (Ed.) The design method. Butterworth, London, pp. 323-330.

Hertenstein, J. H., Platt, M. B., Veryzer, R. W. 2005. The impact of industrial design effectiveness on corporate financial performance. Journal of Product Innovation Management. 22, 3-21.

Hertenstein, J. H., Platt, M. B., Veryzer, R. W. 2013. What is 'good design'? An investigation of the complexity and structure of design. Design Management Journal. 8, 8-21.

Hevner, A. R., March, S. T., Park, J. 2004. Design science in Information Systems research. MIS Quarterly. 28, 75-105.

Hirschman, E. C. 1982. Symbolism and technology as sources for the generation of innovations. Advances in Consumer Research. 9, 537-541.

Johansson-Sköldberg, U., Woodilla, J., Çetinkaya, M. 2013. Design thinking: past, present and possible futures. Creativity and Innovation Management. 22, 121-146.

Johne, F. A., Snelson, P. A. 1988. Success factors in product innovation: a selective review of the literature. Journal of Product Innovation Management. 5, 114-128.

Jones, J. C., Thornley, D. 1963. Conference on design methods, Pergamon, Oxford.

Jones, P., Jordan, J. 1998. Knowledge orientations and team effectiveness. International Journal of Technology Management. 16, 152-161.

Khaire, M. 2012. Brian Moeran and Jesper Strandgaard Pederson, eds.: Negotiating Values in the Creative Industries: Fairs, Festivals, and Competitive Events. Administrative Science Quarterly. 57, 541-544.

Kietzmann, J. H., Hermkens, K., McCarthy, I. P., Silvestre, B. S. 2011. Social media? Get serious! Understanding the functional building blocks of social media. Business Horizons. 54, 241-251.

Kotler, P., Rath, G. A. 1984. Design: a powerful but neglected strategic tool. Journal of Business Strategy. 5, 16-21.

Krippendorff, K. 1989. On the essential contexts of artifacts or on the proposition that "design is making sense (of things)". Design Issues. 5, 9-39.

Krippendorff, K. 2006. The Semantic Turn: A New Foundation for Design, Taylor and Francis, Boca Raton, FL.

Lawson, B. 2006. How designers think: the design process demystified, Architectural Press, Oxford.

Le Masson, P., Hatchuel, A., Weil, B. 2011. The interplay between creativity issues and design theories: a new perspective for design management studies? Creativity and Innovation Management. 20, 217-237. 
Lee, Y., Evans, M. 2012. What drives organizations to employ design-driven approaches? A study of fast-moving consumer goods brand development. Design Management Journal. 7, 74-88.

Lehrer, M., Ordanini, A., DeFillippi, R., Miozzo, M. 2012. Challenging the orthodoxy of value co-creation theory: a contingent view of co-production in design-intensive business services. European Management Journal. 30, 499-509.

Leonard, D., Rayport, J. F. 1997. Spark innovation throught empathic design. Harvard Business Review. 75, 102-113.

Leonard, D., Sensiper, S. 1998. The role of tacit knowledge in group innovation. California Management Review. 40, 112-132.

Li, Y., Wang, J., Li, X., Zhao, W. 2007. Design creativity in product innovation. International Journal of Advanced Manufacturing Technology. 33, 213-222.

Love, T. 2002. Constructing a coherent cross-disciplinary body of theory about designing and designs: some philosophical issues. Design Studies. 23, 345-361.

Luchs, M., Swan, S. 2011. Perspective: the emergence of product design as a field of marketing inquiry. Journal of Product Innovation Management. 28, 327-345.

Maffei, S. 2010. Il progetto è una pratica clinica. La prospettiva del design, in: Fabbri, T. M. (Ed.) Organizzare: concetti e metodi. Carocci, Roma, pp. 265-282.

March, S. T., Smith, G. F. 1995. Design and natural science research on information technology. Decision Support Systems. 15, 251-266.

Martin, R. L. 2009. The design of business: why design thinking is the next competitive advantage, Harvard Business Press, Boston.

McLeod, C., O'Donohoe, S., Townley, B. 2009. The elephant in the room? Class and creative careers in British advertising agencies. Human Relations. 62, 1011-1039.

Micheli, P., Jaina, J., Goffin, K., Lemke, F., Verganti, R. 2012. Perceptions of industrial design: the 'means' and the 'ends'. Journal of Product Innovation Management. 29, 687704.

Moenaert, R. K., Souder, W. E. 1990. An information transfer model for integrating marketing and R\&D personnel in new product development projects. Journal of Product Innovation Management. 7, 91-107.

Moultrie, J., Livesey, F. 2013. Measuring design investment in firms: conceptual foundations and exploratory UK survey. Research Policy. (In press, Corrected proof).

Noble, C. H., Kumar, M. 2010. Exploring the appeal of product design: a grounded, valuebased model of key design elements and relationships*. Journal of Product Innovation Management. 27, 640-657.

Olins, W. 1986. The industrial designer in Britain 1946-82, in: Sparke, P. (Ed.) Did Britain Make It? British Design in Context. Design Council, London, pp. 59-67.

Pandza, K., Thorpe, R. 2010. Management as design, but what kind of design? An appraisal of the design science analogy for management. British Journal of Management. 21, 171186.

Paton, E. 2013a. Creative directors stage boardroom coup. Financial Times, 8 November, Issue no. 8.

Paton, E. 2013b. Tiffany shines amid strong Asia-Pacific diamond demand. Financial Times, 26 November, Issue n. 8. 
Perks, H. 2007. Inter-functional integration and industrial new product portfolio decision making: exploring and articulating the linkages. Creativity and Innovation Management. $16,152-164$.

Perks, H., Cooper, R., Jones, C. 2005. Characterizing the role of design in new product development: an empirically derived taxonomy. Journal of Product Innovation Management. 22, 111-127.

Petroski, H. 1985. To engineer is human: the role of failure in successful design, Macmillan, London.

Petroski, H. 1994. Design paradigms: case histories of error and judgment in engineering, Cambridge University Press, Cambridge.

Petroski, H. 1996. Invention by design: how engineers get from thought to thing, Harvard University Press, Cambridge, MA.

Poetz, M. K., Schreier, M. 2012. The value of crowdsourcing: can users really compete with professionals in generating new product ideas. Journal of Product Innovation Management. 29, 245-256.

Potts, J. 2009. Why creative industries matter to economic evolution. Economics of Innovation and New Technology. 18, 663-673.

Potts, J., Cunningham, S. 2008. Four models of the creative industries. International Journal of Cultural Policy. 14, 233-247.

Ravasi, D., Lojacono, G. 2005. Managing design and designers for strategic renewal. Long Range Planning. 38, 51-77.

Ravasi, D., Marcotti, A., Stigliani, I. 2008. Conditions of success and failure in collaborations between business firms and design consultancies: the designers' perspective, in: The Creative Industries and Intellectual Property. London: DIME.

Ravasi, D., Rindova, V. P. 2008. Symbolic value creation, in: Barry, D. and Hansen, H. (Eds.), The Sage Handbook of New Approaches in Management and Organization. SAGE Publications, London, pp. 270-286.

Ravasi, D., Stigliani, I. 2012. Product design: a review and research agenda for management studies. International Journal of Management Reviews. 14, 464-488.

Razzouk, R., Shute, V. 2012. What is design thinking and why is it important? Review of Educational Research. 82, 330-348.

Romme, A. G. L. 2003. Making a difference: organization as design. Organization Science. $14,558-573$.

Rothwell, R., Gardiner, P. 1983. The role of design in product and process change. Design Studies. 4, 161-169.

Roy, R., Potter, S. 1990. Managing design projects in small and medium-sized firms. Technology Analysis and Strategic Management. 2, 321-336.

Roy, R., Riedel, J. C. 1997. Design and innovation in successful product competition. Technovation. 17, 537-594.

Roy, R., Walsh, V., Salaman, G. 1986. Design based innovation in manufacturing industry: principles and practices for successful design and production. The Open University and UMIST, Report DIG-02.

Roy, R., Wield, D. 1986. Product design and technological innovation: a reader, Open University Press, Milton Keynes.

Rylander, A. 2009. Design thinking as knowledge work: epistemological foundations and practical implications. Design Management Journal. 5, 7-19. 
Sabatier, V., Mangematin, V., Rousselle, T. 2010. From recipe to dinner: business model portfolios in the European biopharmaceutical industry. Long Range Planning. 43, 431447.

Schön, D. A. 1983. The Reflective Practitioner: How Professionals Think in Action, Basic Books, New York.

Simon, H. A. 1969. The Sciences of the Artificial, MIT Press, London.

Sparke, P. 1986. Did Britain make it? British design in context 1946-86, Design Council, London.

Teece, D. J. 2010. Business models, business strategy and innovation. Long Range Planning. 43, 172-194.

Torbett, R., Salter, A. J., Gann, D. M., Hobday, M. 2001. Design performance measurement in the construction sector: a pilot study. SPRU Electronic Working Paper no. 66. 1-47. (available at: http://139.184.32.141/Units/spru/publications/imprint/sewps/sewp66/sewp66.pdf).

Tovey, M., Porter, S., Newman, R. 2003. Sketching, concept development and automotive design. Design Studies. 24, 135-153.

Tran, Y. 2010. Generating stylistic innovation: a process perspective. Industry and Innovation. 17, 131-161.

Trueman, M., Jobber, D. 1998. Competing through design. Long Range Planning. 31, 594605 .

Twigg, D. 1998. Managing product development within a design chain. International Journal of Operations and Production Management. 18, 508-524.

Twigg, D. 2002. Managing the design/manufacturing interface across firms. Integrated Manufacturing Systems. 13, 212-221.

Ulrich, K. 2011. Design is everything? Journal of Product Innovation Management. 28, 394398.

Ulrich, K. T., Eppinger, S. D. 1995. Product design and development, McGraw-Hill Higher Education, London.

Utterback, J., Abernathy, W. J. 1975. A dynamic model of process and product innovation. Omega. 3, 639-656.

Utterback, U., Vedin, B. A., Alvarez, E., Ekman, S., Sanderson, S. W., Tether, B. S., Verganti, R. 2006. Design-inspired innovation, World Scientific Publishing, Singapore.

Verganti, R. 2003. Design as brokering of languages: innovation strategies in Italian firms. Design Management Journal. 14, 34-42.

Verganti, R. 2008. Design, meanings, and radical innovation: a metamodel and a research agenda. Journal of Product Innovation Management. 25, 436-456.

Verganti, R. 2009. Design-driven innovation - Changing the rules of competition by radically innovating what things mean, Harvard Business Press, Boston.

Veryzer, R. W. 2000. Design and consumer research. Design Management Journal Academic Review. 1, 64-73.

Veryzer, R. W. 2005. The roles of marketing and industrial design in discontinuous new product development. Journal of Product Innovation Management. 22, 22-41.

Vincenti, W. G. 1990. What engineers know and how they know it. Analytical studies from aeronautical history, The John Hopkins University Press, London.

von Stamm, B. 1997. Whose design is it? The use of external designers. Design Journal. 1, 41-53. 
von Stamm, B. 2008. Managing innovation, design and creativity, John Wiley \& Sons, Chichester.

Walsh, V. 1996. Design, innovation and the boundaries of the firm. Research Policy. 25, 509529.

Walsh, V., Roy, R. 1983. Plastic products: good design, innovation and business success. The Open University and UMIST, Report DIG-01.

Walsh, V., Roy, R. 1985. The designer as 'gatekeeper' in manufacturing industry. Design Studies. 6, 127-133.

Walsh, V., Roy, R., Bruce, M., Potter, S. 1992. Winning by design: technology, product design and international competitiveness, Blackwell Publishers, Oxford.

West, J., Bogers, M. 2014. Leveraging external sources of innovation: a review of research on open innovation. Journal of Product Innovation Management. 31, 1-52.

Wijnberg, N. M. 2004. Innovation and organization: value and competition in selection systems. Organization Studies. 25, 1413-1433.

Witell, L., Kristensson, P., Gustafsson, A., Löfgren, M. 2011. Idea generation: customer cocreation versus traditional market research. Journal of Service Management. 22, 140-159.

Witt, U. 2001. Escaping Satiation: The Demand Side of Economic Growth, Springer, New York.

Wray, G. R. 1991. Design or decline - a national emergency. Proceedings of the Institution of Mechanical Engineers, Part B. 205, 153-170.

Wrigley, C. J. 2011. Visceral Hedonic Rhetoric. Degree of Doctor of Philosophy, Unpublished PhD Thesis submitted at Queensland University of Technology.

Yang, M. C. 2009. Observations on concept generation and sketching in engineering design. Research Engineering Design. x, 1-11.

Zott, C., Amit, R. 2007. Business model design and the performance of entrepreneurial firms. Organization Science. 18, 181-199.

Zott, C., Amit, R. 2010. Business model design: an activity system perspective. Long Range Planning. 43, 216-226.

Zott, C., Amit, R., Massa, L. 2011. The business model: recent developments and future research. Journal of Management. 37, 1019-1042. 
Table 1: The evolving nature of design and its dimensions

\begin{tabular}{|c|c|c|c|c|c|}
\hline & \multicolumn{2}{|l|}{ Creative dimension } & Shaping dimension & \multicolumn{2}{|c|}{ Applicative dimension } \\
\hline & $\begin{array}{l}\text { DESIGN AS CREATION } \\
\text { OF ARTEFACTS }\end{array}$ & $\begin{array}{l}\text { DESIGN AS A Problem- } \\
\text { SOLVING ACTIVITY }\end{array}$ & $\begin{array}{l}\text { Design AS A REFLEXIVE } \\
\text { PRACTICE* }\end{array}$ & $\begin{array}{l}\text { DESIGN AS MAKING } \\
\text { SENSE OF THINGS* }\end{array}$ & $\begin{array}{l}\text { DESIGN AS A KEY INPUT } \\
\text { TO STRATEGY }\end{array}$ \\
\hline Definition & $\begin{array}{l}\text { Design research consists of } \\
\text { studying, researching, and } \\
\text { investigating the artificial made } \\
\text { by human beings and the way } \\
\text { these activities have been explored } \\
\text { in academia or employed in } \\
\text { manufacturing. }\end{array}$ & $\begin{array}{l}\text { Design is a problem-solving activity } \\
\text { involving the definition of the } \\
\text { problem, the identification and } \\
\text { generation of alternative solutions, } \\
\text { and the evaluation and selection of } \\
\text { the most suitable one(s). }\end{array}$ & $\begin{array}{l}\text { By complementing Simon's } \\
\text { cognitive perspective, the designer } \\
\text { is conceived as a practitioner } \\
\text { focusing on the relation between } \\
\text { creation and reflection-upon-the- } \\
\text { creation that allows for constantly } \\
\text { improved competence and re-creation. }\end{array}$ & $\begin{array}{l}\text { While in the same tradition } \\
\text { initiated by Schön, here abductive } \\
\text { processes are used to make sense } \\
\text { of and generalise from } \\
\text { observations. Thus design finds its } \\
\text { expression in practical experience } \\
\text { and can be ascribed through } \\
\text { practical examples. }\end{array}$ & $\begin{array}{l}\text { Design relates directly to the } \\
\text { strategy of the firm. It seeks to } \\
\text { optimise consumer satisfaction and } \\
\text { company profitability through the } \\
\text { creation of form, durability, and } \\
\text { values along with products } \\
\text { environments, information, and } \\
\text { identities. }\end{array}$ \\
\hline Source & Simon (1969) & March and Smith (1995) & Schön (1983) & Lawson (2006), Cross (2006) & Kotler and Rath (1984) \\
\hline $\begin{array}{l}\text { Other relevant } \\
\text { sources }\end{array}$ & Krippendorff $(1989,2006)$ & Buchanan (1992), Petroski (1996) & $\begin{array}{l}\text { Bousbaci (2008), Dorst (1996), } \\
\text { Rylander (2009) }\end{array}$ & Cross (1997), Gero (1990) & $\begin{array}{l}\text { Dumas and Whitfield (1989), } \\
\text { Gemser and Leenders (2001) }\end{array}$ \\
\hline Implications & $\begin{array}{l}\text { Design is conceived as the activity } \\
\text { aiming at exploring the creative } \\
\text { input of individuals and/or firms } \\
\text { and how it is shaped for the } \\
\text { implementation within firms or } \\
\text { other entities. }\end{array}$ & $\begin{array}{l}\text { Reconsidering the role of design } \\
\text { know-how in new product } \\
\text { development and innovation } \\
\text { processes. }\end{array}$ & $\begin{array}{l}\text { Managers are well aware of the } \\
\text { important areas of practice that fall } \\
\text { outside of technical rationality. } \\
\text { While dealing with decisions under } \\
\text { uncertainty, managers develop a } \\
\text { problem-solving ability based on } \\
\text { intuition rather than the study of } \\
\text { theory or techniques. }\end{array}$ & $\begin{array}{l}\text { Design represents the negotiation } \\
\text { between problem and solution } \\
\text { through the activities of analysis, } \\
\text { synthesis, and evaluation. The } \\
\text { designer plays a prescriptive role } \\
\text { as (s)he describes how the world } \\
\text { might be. }\end{array}$ & $\begin{array}{l}\text { Design is conceived as the means to } \\
\text { increase the competitiveness of firms. } \\
\text { This dimension of design captures the } \\
\text { possibility to apply design reasoning } \\
\text { and principles to the formulation } \\
\text { and execution of strategy. }\end{array}$ \\
\hline
\end{tabular}

* Inspired by Johansson-Sköldberg et al. (2013). 


\section{Appendix Table 1: Existing reviews of the design literature}

\begin{tabular}{|c|c|c|c|}
\hline Publication $^{(1)}$ & Aim of the review & Methodology & Field(s) \\
\hline Bloch (1995) & $\begin{array}{l}\text { Introducing a conceptual model and several propositions that } \\
\text { describe how the form of a product relates to consumer } \\
\text { psychology and behaviour. }\end{array}$ & Qualitative & Marketing \\
\hline $\begin{array}{l}\text { Noble and Kumar } \\
(2010)\end{array}$ & $\begin{array}{l}\text { Eliciting the key dimensions of design and developing an enriched } \\
\text { language for its understanding. Integrating the design dimensions within } \\
\text { a broader model that ties initial design goals with likely psychological } \\
\text { and behavioural responses from consumers. Proposing a framework } \\
\text { for the creation of design value in consumer products. }\end{array}$ & $\begin{array}{l}\text { Qualitative } \\
\text { (grounded } \\
\text { theory) }\end{array}$ & $\begin{array}{l}\text { Innovation } \\
\text { management }\end{array}$ \\
\hline $\begin{array}{l}\text { Le Masson et al. } \\
\text { (2011) }\end{array}$ & $\begin{array}{l}\text { Analysing the relationship between creativity issues and design theory } \\
\text { and pointing to the dialectical interplay that links them, structured } \\
\text { around the notion of 'fixation effect'. Arguing that these design theories } \\
\text { could open new paths to reflect on ways of managing design-related } \\
\text { knowledge, processes and organisations, which will have an impact on } \\
\text { wider innovation management issues. }\end{array}$ & Qualitative & $\begin{array}{l}\text { Creativity } \\
\text { and } \\
\text { innovation } \\
\text { management }\end{array}$ \\
\hline $\begin{array}{l}\text { Luchs and Swan } \\
\text { (2011) }\end{array}$ & $\begin{array}{l}\text { Reviewing articles on product design published in the eight leading } \\
\text { journals (covering the period 1995-2008) important to marketing } \\
\text { thought. Proposing a conceptual model of product design and offering a } \\
\text { definition for product design and product design process. Providing } \\
\text { insights into the nature of product design research during this time } \\
\text { period, including analysis of publication trends and the relationship of } \\
\text { product design research to related marketing topics. }\end{array}$ & Quantitative & $\begin{array}{l}\text { Marketing } \\
\text { and } \\
\text { management }\end{array}$ \\
\hline $\begin{array}{l}\text { Ravasi and Stigliani } \\
(2012)\end{array}$ & $\begin{array}{l}\text { Reviewing the literature on product design within the business studies } \\
\text { domain. Proposing a segmentation of the literature in three core areas } \\
\text { that correspond to different perceptions of design: design as an activity, } \\
\text { design as a choice, and the results of design. }\end{array}$ & Quantitative & Management \\
\hline
\end{tabular}

(1) All sources are academic journals. 
Appendix Table 2: Segmenting the scholarly contribution to the discipline of $\operatorname{design}^{(a)}$

\begin{tabular}{|c|c|c|c|c|}
\hline Publication $^{(1)}$ & Focus & Keywords & Methodology & Field(s) \\
\hline \multicolumn{5}{|c|}{ Design and the interpretation of consumers' needs (please refer to Section 3.1 of the manuscript) } \\
\hline Gregory $(1966 a)^{*}$ & Drawing the distinction between scientific method and design method. & Design method & Qualitative & Computer science \\
\hline Simon $(1969)^{*}$ & $\begin{array}{l}\text { Contribute to building a science of design; developing systematic and formalised design } \\
\text { methodologies. }\end{array}$ & Sciences of the artificial, design science & Qualitative & $\begin{array}{l}\text { Engineering, } \\
\text { computer science }\end{array}$ \\
\hline Cross et al. (1981) & $\begin{array}{l}\text { Contributing to the debate on whether design is a scientific method. Proposing to regard } \\
\text { design as a technology instead. Calling for the application of types of knowledge beyond } \\
\text { the 'purely' scientific kind. }\end{array}$ & $\begin{array}{l}\text { Science of design, design science, design } \\
\text { as a technology }\end{array}$ & Qualitative & Design studies \\
\hline $\begin{array}{l}\text { Rothwell and Gardiner } \\
\text { (1983) }\end{array}$ & $\begin{array}{l}\text { Discussing that for design to be successful it needs to be dynamic in nature and meet changing } \\
\text { demands. Emphasising the role of the innovative user in defining appropriate functional design } \\
\text { specifications of engineering products. }\end{array}$ & $\begin{array}{l}\text { Engineering design, makeability, user / } \\
\text { producer interaction }\end{array}$ & Quantitative & Design studies \\
\hline Petroski $(1985)^{*}$ & Underlying the importance of failure in the processes of new product design and development. & Engineering design, failure, design & Qualitative & Engineering design \\
\hline Gero (1990) & $\begin{array}{l}\text { By describing design as a process, the paper introduces a knowledge representation schema } \\
\text { for design (prototypes), which supports the initiation and continuation of the act of designing. }\end{array}$ & $\begin{array}{l}\text { Design as a process, knowledge } \\
\text { representation, design prototypes }\end{array}$ & Mixed method & Computer science \\
\hline Vincenti $(1990)^{*}$ & $\begin{array}{l}\text { Showing how engineering knowledge is obtained; presenting a model to help explain the } \\
\text { growth of this knowledge. }\end{array}$ & Engineering design, design knowledge & Mixed method & Engineering design \\
\hline Cross (1993) & $\begin{array}{l}\text { Review of the relatively short history of design methodology and its relationships with science. } \\
\text { Mapping out major themes. Drawing the boundaries for a shared understanding of scientific } \\
\text { design. }\end{array}$ & $\begin{array}{l}\text { Design methodology, design science, } \\
\text { science of design }\end{array}$ & Qualitative & Engineering design \\
\hline Petroski $(1994)^{*}$ & $\begin{array}{l}\text { Reviewing different case histories showing how the understanding of failure for design } \\
\text { processes is similarly important in contexts where design is undertaken individually or in } \\
\text { group, with or without the support of computer-based means. }\end{array}$ & Design knowledge, engineering design & Qualitative & Design science \\
\hline March and Smith (1995) & $\begin{array}{l}\text { Advancing research in Information Technology (IT). Introducing a framework for research } \\
\text { in IT with two dimensions: one based on broad types of design and natural science research } \\
\text { activities (build, evaluate theorise, justify) and one based on broad types of outputs produced } \\
\text { by design research (representational constructs, models, methods, instantiations). }\end{array}$ & $\begin{array}{l}\text { Information system research, design } \\
\text { science, natural science, information } \\
\text { technology }\end{array}$ & Qualitative & Decision science \\
\hline Petroski $(1996)^{*}$ & $\begin{array}{l}\text { Exploring the nature of engineering and technology through case studies of familiar objects; } \\
\text { the final aim is to illuminate different facets of the engineering enterprise - design, analysis, } \\
\text { failure, economics, aesthetics, communications, politics, and quality control. }\end{array}$ & $\begin{array}{l}\text { Design knowledge, invention, } \\
\text { engineering }\end{array}$ & Qualitative & Engineering design \\
\hline Veryzer (2000) & $\begin{array}{l}\text { Even though design (inclusive of aesthetics) has been studied for centuries, there continues } \\
\text { to be a great deal of uncertainty and ambiguity concerning design and people's reactions to it. } \\
\text { A body of work in the field of consumer research has investigated design and aesthetic } \\
\text { response with respect to its influence on consumer behaviour. This paper discusses work done } \\
\text { in the field of consumer research that relates to design, and examines some of the implications } \\
\text { of this body of work for design management and design management research. }\end{array}$ & $\begin{array}{l}\text { Consumer research, design, aesthetics, } \\
\text { management implications }\end{array}$ & Qualitative & $\begin{array}{l}\text { Innovation and } \\
\text { design studies }\end{array}$ \\
\hline
\end{tabular}

(1) All sources are academic journals unless otherwise specified (* for 'book', ' for 'working paper', ' for 'conference proceedings'). 


\section{Appendix Table 2 (continued)}

\begin{tabular}{|c|c|c|c|c|}
\hline Publication $^{(1)}$ & Focus & Keywords & Methodology & Field(s) \\
\hline Love (2002) & $\begin{array}{l}\text { Exploring philosophical problems associated with building a unified and coherent cross- } \\
\text { disciplinary body of knowledge and theory associated with designing and designs. Describing } \\
\text { general criteria for improving the definitions of concepts and theories. Outlining relationships } \\
\text { and boundaries between design research and other nine disciplinary areas. }\end{array}$ & $\begin{array}{l}\text { Philosophy of design, design theory, } \\
\text { epistemology, interdisciplinary, science } \\
\text { of design }\end{array}$ & Qualitative & Design studies \\
\hline Hevner et al. (2004) & $\begin{array}{l}\text { Describing the performance of design-science research in Information Systems (IS) via a } \\
\text { concise conceptual framework and clear guidelines for a better understanding, evaluation, and } \\
\text { execution of this body of knowledge. }\end{array}$ & $\begin{array}{l}\text { IS research methodologies, design artefact, } \\
\text { technology infrastructure, search strategies, } \\
\text { experimental methods, creativity }\end{array}$ & Qualitative & $\begin{array}{l}\text { Information system, } \\
\text { design science }\end{array}$ \\
\hline $\begin{array}{l}\text { Creusen and Schoormans } \\
\text { (2005) }\end{array}$ & $\begin{array}{l}\text { Identifying three ways in which the appearance of a product influences consumers' product } \\
\text { choices. Differentiating among different roles of product appearance (communication of } \\
\text { aesthetic, symbolic, functional, ergonomic information, attention drawing, and categorisation) } \\
\text { to help product development managers optimise product appearance. }\end{array}$ & $\begin{array}{l}\text { Product design, firm success, product } \\
\text { appearance }\end{array}$ & Mixed method & $\begin{array}{l}\text { Innovation } \\
\text { management }\end{array}$ \\
\hline Gregor (2009) & $\begin{array}{l}\text { Continuing Herbert Simon's quest for a science of design, yet with a more holistic manner } \\
\text { across the whole of a science of the artificial questioning whether the Scientific Method } \\
\text { applies to the sciences of the artificial, and what are the challenges for theorising encountered. }\end{array}$ & Sciences of the artificial, theory building & Qualitative & $\begin{array}{l}\text { Sciences of the } \\
\text { artificial }\end{array}$ \\
\hline Verganti (2009)* & $\begin{array}{l}\text { Unveiling how leaders such as Apple, Nintendo, Alessi and Whole Foods Market build a solid } \\
\text { market and sustainable competitive advantage through innovations that do not come from the } \\
\text { market, yet create new markets. Arguing that competition among these players takes place } \\
\text { through radical new meanings. }\end{array}$ & $\begin{array}{l}\text { Design-driven innovation, rules of } \\
\text { competition }\end{array}$ & Qualitative & $\begin{array}{l}\text { Design and } \\
\text { innovation }\end{array}$ \\
\hline Maffei (2010)* & $\begin{array}{l}\text { Arguing that design project contains an element of organisation. Design has to do with defining } \\
\text { the form of the artefacts, but also with the process in place to achieve these artefacts. }\end{array}$ & Design as a project & Qualitative & Design science \\
\hline Ulrich (2011) & $\begin{array}{l}\text { Defining product design as conceiving and giving form to goods and services that address } \\
\text { needs and comprising several key decisions. Arguing that, since the decisions related to } \\
\text { product design do not map cleanly to any one academic discipline, the subject has not garnered } \\
\text { enough attention in any one field to fully develop its own academic identity. }\end{array}$ & $\begin{array}{l}\text { Product design, decisions, methodological } \\
\text { paradigm, industrial practice of design }\end{array}$ & Qualitative & $\begin{array}{l}\text { Innovation } \\
\text { management }\end{array}$ \\
\hline Bogers and Horst (2013) & $\begin{array}{l}\text { Exploring how collaborative prototyping across functional, hierarchical, and organisational } \\
\text { boundaries can improve the overall prototyping process. Suggesting the existence of two levels } \\
\text { of prototyping: the managerial vs. the designer level; on this latter, collaborative prototyping } \\
\text { transforms the act of prototyping from an activity belonging exclusively to the domain of } \\
\text { design engineers to an activity integral to NPD, with internal and external participants. }\end{array}$ & $\begin{array}{l}\text { Collaborative prototyping, cross- } \\
\text { fertilisation of knowledge, users, } \\
\text { problem solving, product design }\end{array}$ & Qualitative & $\begin{array}{l}\text { Innovation } \\
\text { management }\end{array}$ \\
\hline \multicolumn{5}{|c|}{ Design and firms' organisational structure (please refer to Section 3.2.1 of the manuscript) } \\
\hline Walsh and Roy (1985) & $\begin{array}{l}\text { Employment and activities of product designers and their role as 'gatekeepers' who, in the } \\
\text { commercially successful, 'design-conscious' firms, manage to integrate the contributions of } \\
\text { marketing, design and production in new product development. }\end{array}$ & $\begin{array}{l}\text { Design philosophy, manufacturing, } \\
\text { plastics }\end{array}$ & Quantitative & Design science \\
\hline Black and Baker (1987) & $\begin{array}{l}\text { Emphasising the methodological problems of researching design in small companies. } \\
\text { Suggesting some methods for overcoming these problems. Showing that design and marketing } \\
\text { are involved to a greater extent during new product development in successful companies } \\
\text { than unsuccessful ones. }\end{array}$ & $\begin{array}{l}\text { Product design, competitiveness, small } \\
\text { companies }\end{array}$ & Quantitative & Design science \\
\hline
\end{tabular}

(1) All sources are academic journals unless otherwise specified (* for 'book', ' for 'working paper', ' for 'conference proceedings'). 


\section{Appendix Table 2 (continued)}

\begin{tabular}{|c|c|c|c|c|}
\hline Publication $^{(1)}$ & Focus & Keywords & Methodology & Field(s) \\
\hline $\begin{array}{l}\text { Dumas and Whitfield } \\
\text { (1989) }\end{array}$ & $\begin{array}{l}\text { Investigating the practices of design management in Great Britain. Among the main findings: } \\
\text { (a) the existence of four distinct types of company, each with their own approach to design, } \\
\text { (b) the influence of the design manager on firms' decision making, and (c) the clear-cut } \\
\text { distinction between manufacturing and service sectors. }\end{array}$ & $\begin{array}{l}\text { Design management, manufacturing and } \\
\text { service firms }\end{array}$ & Quantitative & Management \\
\hline Bruce and Morris (1994) & $\begin{array}{l}\text { Delineating a taxonomy of different approaches to design management and discussing various } \\
\text { issues attached to it. Finding that the relationship between design suppliers and buyers can } \\
\text { vary from being a long-term close relationship to an arm's-length and distanced one. }\end{array}$ & $\begin{array}{l}\text { External design professionals, product } \\
\text { development process }\end{array}$ & Qualitative & $\begin{array}{l}\text { Technology and } \\
\text { innovation } \\
\text { management }\end{array}$ \\
\hline Dickson et al. (1995) & $\begin{array}{l}\text { Fostering a better understanding of product design skills in small high-growth firms by asking } \\
\text { three fundamental questions: which aspects of design management the CEOs of small, high- } \\
\text { growth firms believe they manage well; to what extent the CEOs are involved in design } \\
\text { decisions; and how relevant good product design is for these firms. In more than half of the } \\
\text { surveyed companies, CEOs seemed to have a primary responsibility in design decisions. }\end{array}$ & $\begin{array}{l}\text { Product design, high-growth small firms, } \\
\text { CEOs' decision making }\end{array}$ & Quantitative & $\begin{array}{l}\text { Innovation } \\
\text { management }\end{array}$ \\
\hline Walsh (1996) & $\begin{array}{l}\text { Analysing the design function from an economic, sociological and management } \\
\text { perspective. Comparing design with R\&D and technological innovations. }\end{array}$ & $\begin{array}{l}\text { Design function, design activities, } R \& D \\
\text { and technological innovation }\end{array}$ & Qualitative & Innovation \\
\hline Roy and Riedel (1997) & $\begin{array}{l}\text { Identifying the contribution of design and innovation to product competitiveness in different } \\
\text { markets. Providing a conceptual analysis of the role of design on product competition. }\end{array}$ & $\begin{array}{l}\text { Successful innovation, design, product } \\
\text { competition, product development }\end{array}$ & Quantitative & $\begin{array}{l}\text { Innovation and } \\
\text { technology }\end{array}$ \\
\hline von Stamm (1997) & $\begin{array}{l}\text { Elaborating on the different choices an organisation has in terms of employing an internal or } \\
\text { external designer, or how to structure and manage the relationship between designer and } \\
\text { commissioning organisation. The case study of the design and development process of a } \\
\text { motorbike, for which an external design consultancy was employed, is used to illustrate issues } \\
\text { surrounding the relationship between external designer and company. }\end{array}$ & External designers, design outsourcing & Qualitative & Design studies \\
\hline $\begin{array}{l}\text { Trueman and Jobber } \\
\text { (1998) }\end{array}$ & $\begin{array}{l}\text { Investigating the subject and the role of design in new product developments; identifying } \\
\text { design attributes that may have a positive influence on the innovation process and grouping } \\
\text { them into four dimensions, namely: values, image, process, and production (VIPP). Testing } \\
\text { this approach by exploring how managers would deal with it. }\end{array}$ & $\begin{array}{l}\text { Competitive advantage through design, } \\
\text { Values Image, Process and Production } \\
\text { (VIPP) }\end{array}$ & Mixed method & $\begin{array}{l}\text { Strategic } \\
\text { management }\end{array}$ \\
\hline Twigg (1998) & $\begin{array}{l}\text { The paper draws on the findings of a study of design chain management in the UK automotive } \\
\text { industry, where the design relationship of six suppliers with the Rover Group are examined. } \\
\text { By focusing on the mechanisms used to manage this relationship, the implications of these for } \\
\text { the management process of customer and supplier are considered. }\end{array}$ & $\begin{array}{l}\text { Design and development, suppliers, } \\
\text { competitive advantage, production, } \\
\text { integration }\end{array}$ & Qualitative & $\begin{array}{l}\text { Operations and } \\
\text { production } \\
\text { management }\end{array}$ \\
\hline Bruce et al. (1999) & $\begin{array}{l}\text { Exploring how small firms invest in design expertise to develop new products and corporate } \\
\text { identities to communicate their services. Finding that design has contributed to the success } \\
\text { of those firms that employed design effectively. However, expertise in sourcing, briefing, } \\
\text { liaising, and evaluating design were varied, thus training small companies in design } \\
\text { management skills is also needed. }\end{array}$ & $\begin{array}{l}\text { Design management, design strategy, } \\
\text { small firms, design investment }\end{array}$ & Qualitative & Design studies \\
\hline Ahire and Dreyfus (2000) & $\begin{array}{l}\text { Establishing a framework for identifying the synergistic linkages of design and process } \\
\text { management to the operational quality outcomes during the manufacturing process (internal } \\
\text { quality) and upon products' field usage (external quality). }\end{array}$ & $\begin{array}{l}\text { Design management, process } \\
\text { management, product quality, empirical, } \\
\text { structural equations modelling. }\end{array}$ & Quantitative & $\begin{array}{l}\text { Operations } \\
\text { management }\end{array}$ \\
\hline Twigg (2002) & $\begin{array}{l}\text { Proposing a typology of inter-firm mechanisms for firms to integrate design and manufacturing } \\
\text { operations in product development. Paper based on a review of the literature on design- } \\
\text { manufacturing integration at firm level. }\end{array}$ & $\begin{array}{l}\text { Co-ordination, design, integration, } \\
\text { product development, manufacturing, } \\
\text { suppliers }\end{array}$ & Qualitative & $\begin{array}{l}\text { Innovation } \\
\text { management }\end{array}$ \\
\hline
\end{tabular}

${ }^{(1)}$ All sources are academic journals unless otherwise specified (* for 'book', ' for 'working paper', ' for 'conference proceedings'). 


\section{Appendix Table 2 (continued)}

\begin{tabular}{|c|c|c|c|c|}
\hline Publication $^{(1)}$ & Focus & Keywords & Methodology & Field(s) \\
\hline Beverland (2005) & $\begin{array}{l}\text { Exploring the tensions between marketing and design and the integration of design into the } \\
\text { brand management process in luxury wine firms. Describing five design-based values held by } \\
\text { luxury winemakers: remaining true to craft, expressions of place, stylistic consistency, living } \\
\text { up to the brand's heritage, and remaining current. While identifying five methods of } \\
\text { integrating design into the firm, the author argues that designers walk a fine line between } \\
\text { their commitment to their values and the ongoing evolution of the brand. }\end{array}$ & Fine line between design and marketing & Qualitative & $\begin{array}{l}\text { Innovation } \\
\text { management }\end{array}$ \\
\hline Perks et al. (2005) & $\begin{array}{l}\text { Exploring the nature of the role of design within the NPD process. Proposing a taxonomy } \\
\text { characterising three roles for design in NPD: design as a functional specialism; design as part } \\
\text { of a multi-functional team; and designers as process leaders. Exploring the implications of } \\
\text { these findings for the development of design skills and capabilities particularly in terms of } \\
\text { recruitment, training, and educational policies. }\end{array}$ & $\begin{array}{l}\text { Role of design in NPD, design skills, } \\
\text { design capabilities }\end{array}$ & Qualitative & $\begin{array}{l}\text { Innovation } \\
\text { management }\end{array}$ \\
\hline $\begin{array}{l}\text { Ravasi and Lojacono } \\
\text { (2005) }\end{array}$ & $\begin{array}{l}\text { Developing a framework that can explore how design and designers can contribute to corporate } \\
\text { strategic renewal. Describing design-driven renewal as a four-phase process stimulated and } \\
\text { supported by design, combining continuous product innovation with the periodic revision of } \\
\text { the strategic course of the company. Finally, discussing the specific role of manager. }\end{array}$ & $\begin{array}{l}\text { Strategic renewal, design management, } \\
\text { role of designers, role of managers }\end{array}$ & Qualitative & $\begin{array}{l}\text { Strategic } \\
\text { management }\end{array}$ \\
\hline Veryzer (2005) & $\begin{array}{l}\text { Examining the roles of marketing and industrial design in the product development process } \\
\text { for discontinuous innovations. Questions concerning how and the degree to which marketing } \\
\text { and industrial design are integrated into the development process are investigated. }\end{array}$ & $\begin{array}{l}\text { Discontinuous innovation, marketing, } \\
\text { industrial design, product discontinuity, } \\
\text { process formality }\end{array}$ & Mixed method & $\begin{array}{l}\text { Innovation } \\
\text { management }\end{array}$ \\
\hline Chiva and Alegre (2007) & $\begin{array}{l}\text { Dealing with the fit between design management skills and design function organisation, } \\
\text { ranging from solely in-house to solely outsourced and including a mixture of the two. } \\
\text { Demonstrating how firms with a solely in-house design approach are the most skilled, whilst } \\
\text { firms adopting a solely outsourced approach are the least skilled ones. }\end{array}$ & Design management, ceramic tile & Quantitative & $\begin{array}{l}\text { Technology and } \\
\text { innovation } \\
\text { management }\end{array}$ \\
\hline von Stamm (2008)* & $\begin{array}{l}\text { Exploring the motivations for which firms decide to either develop in-house or outsource } \\
\text { design expertise or yet to combine these two ways of managing design. Exploring the } \\
\text { implications in terms of performance and strategy. }\end{array}$ & $\begin{array}{l}\text { Design management, managing creativity, } \\
\text { in-house vs. outsourcing of design }\end{array}$ & Mixed method & $\begin{array}{l}\text { Innovation and } \\
\text { design studies }\end{array}$ \\
\hline $\begin{array}{l}\text { Dell'Era and Verganti } \\
\text { (2010) }\end{array}$ & $\begin{array}{l}\text { Emphasising the importance of managing the collaborations with designers for companies that } \\
\text { operate in design-intensive industries. Illustrating how firms can develop a proper collaborative } \\
\text { strategy by identifying an effective portfolio of designers. Arguing that innovativeness does not } \\
\text { depend on diversity brought by an individual designer, but on diversity brought by the entire } \\
\text { portfolio of designers of a firm. }\end{array}$ & $\begin{array}{l}\text { Collaborative strategies, portfolio of } \\
\text { external designers }\end{array}$ & Quantitative & $\begin{array}{l}\text { Strategic } \\
\text { management }\end{array}$ \\
\hline Filippetti $(2010)^{\dagger}$ & $\begin{array}{l}\text { Designers are very often located outside the firm, an aspect that raises a central management } \\
\text { issue for the firm. The paper sheds light on this complex relationship drawing on a multiple } \\
\text { case study. The findings confirm that design consultants can make a substantial contribution in } \\
\text { enhancing firms' innovation capabilities. The author argues that it is key to develop a better } \\
\text { understanding of the types of knowledge designers need for their activity, as this would affect } \\
\text { the way design consultants are integrated within the organisational structure of the firm. }\end{array}$ & $\begin{array}{l}\text { Industrial design, innovation, product } \\
\text { development, case study }\end{array}$ & Qualitative & Innovation \\
\hline
\end{tabular}

${ }^{(1)}$ All sources are academic journals unless otherwise specified (* for 'book', ' for 'working paper', ' for 'conference proceedings'). 


\section{Appendix Table 2 (continued)}

\begin{tabular}{|c|c|c|c|c|}
\hline Publication ${ }^{(1)}$ & Focus & Keywords & Methodology & Field(s) \\
\hline $\begin{array}{l}\text { Abecassis-Moedas and } \\
\text { Benghozi (2012) }\end{array}$ & $\begin{array}{l}\text { Analysing why firms use both internal and external design to develop a better understanding of } \\
\text { the determinants of design architecture choices. Mobilising the concept of vertical architecture } \\
\text { that designates the configurations of transactional choices along the firms' value chain. } \\
\text { Identifying three determinants of design architecture choices (efficiency, level of fashion } \\
\text { innovativeness, and innovation type) that can be grouped into two main opposing determinants: } \\
\text { efficiency and innovativeness. }\end{array}$ & $\begin{array}{l}\text { Design architecture, design choices, } \\
\text { external design }\end{array}$ & Qualitative & $\begin{array}{l}\text { Innovation } \\
\text { management }\end{array}$ \\
\hline $\begin{array}{l}\text { Utterback and Abernathy } \\
\text { (1975) }\end{array}$ & $\begin{array}{l}\text { Arguing that the characteristics of innovation processes will correspond systematically with the } \\
\text { stage of development exhibited by the firm's production technology and with its strategy for } \\
\text { competition and growth. These relationships predict that there will be coherent patterns in the } \\
\text { stimuli for innovation (market, production or new technology), in the types of innovation } \\
\text { (product or process, original or adopted, etc.), and in barriers to innovation. }\end{array}$ & $\begin{array}{l}\text { Competitive strategy, innovation, product } \\
\text { and process innovation, barriers to } \\
\text { innovation }\end{array}$ & Quantitative & $\begin{array}{l}\text { Management } \\
\text { science }\end{array}$ \\
\hline Kotler and Rath (1984) & $\begin{array}{l}\text { Arguing that design is a potent strategic tool that companies can use to gain a sustainable } \\
\text { competitive advantage, yet it is widely neglected. Suggesting that good design can enhance } \\
\text { products, environment, communications, and corporate identity. }\end{array}$ & Design, strategic tool & Quantitative & Business strategy \\
\hline \multicolumn{5}{|c|}{ Design and the strategy of the firm (please refer to Section 3.2.2 of the manuscript) } \\
\hline $\begin{array}{l}\text { Cooper and Kleinschmidt } \\
\text { (1987) }\end{array}$ & $\begin{array}{l}\text { Classifying success and non-success factors by investigating over } 200 \text { new product case } \\
\text { histories. Addressing three performance dimensions that help identify what is meant by } \\
\text { 'new product success': financial performance, opportunity window, and market impact. }\end{array}$ & $\begin{array}{l}\text { Product design, success factors, new } \\
\text { product development, performance, } \\
\text { product management }\end{array}$ & Quantitative & Design science \\
\hline Gorb and Dumas (1987) & $\begin{array}{l}\text { Developing a methodology used to examine how design is organised. Using matrices to } \\
\text { explore the interaction of design with other business functions, the report suggests that } \\
\text { 'silent design' (that is design by people who are not designers and are not aware that they are } \\
\text { participating to design) goes on in all the organisations examined, even those with formal } \\
\text { design policies and open design activities. }\end{array}$ & $\begin{array}{l}\text { Design activity, methodology, interaction } \\
\text { with non-designers, silent design }\end{array}$ & Qualitative & Design studies \\
\hline Borja De Mozota $(1990)^{*}$ & Arguing that design is strictly intertwined with firms' strategic decision making. & Design as a strategic management tool & Qualitative & $\begin{array}{l}\text { Design } \\
\text { management }\end{array}$ \\
\hline Bruce et al. (1995) & $\begin{array}{l}\text { Investigating the risks and rewards of investing in professional design expertise at project or } \\
\text { product level and finding that such investment involves relatively low risks and can yield } \\
\text { substantial rewards by opening up new markets and enhancing profitability. Arguing that } \\
\text { proper briefing of designers, regular communication between marketing, design and production, } \\
\text { and effective project management, can make the difference between success and failure. }\end{array}$ & $\begin{array}{l}\text { Design investment, management skills, } \\
\text { design expertise }\end{array}$ & Quantitative & Marketing \\
\hline Cooper and Press $(1995)^{*}$ & $\begin{array}{l}\text { Analysing the emergence and development of the designer within firms. Arguing that their } \\
\text { role as a consultant rather than employees was defined by the pioneering American industrial } \\
\text { designers of the 1930s, such as Raymond Lower and Walter Dorwing Teague, who were } \\
\text { interpreting their function as market-driven jobbing stylists. }\end{array}$ & Design management & Qualitative & $\begin{array}{l}\text { Strategic } \\
\text { management }\end{array}$ \\
\hline $\begin{array}{l}\text { Gemser and Leenders } \\
\text { (2001) }\end{array}$ & $\begin{array}{l}\text { Exploring how and when integrating industrial design in new product development processes } \\
\text { can enhance a company's competitive position. }\end{array}$ & $\begin{array}{l}\text { Industrial design, company performance, } \\
\text { product development process }\end{array}$ & Quantitative & $\begin{array}{l}\text { Innovation } \\
\text { management }\end{array}$ \\
\hline
\end{tabular}




\section{Appendix Table 2 (continued)}

\begin{tabular}{|c|c|c|c|c|}
\hline Publication $^{(1)}$ & Focus & Keywords & Methodology & Field(s) \\
\hline Lawson (2006)* & $\begin{array}{l}\text { Describing design as a process, how that process works, what we understand about it and what } \\
\text { we do not, and how it is learned and performed by professionals and experts. Summarising } \\
\text { various researches and experiment works with design and designers, both professionals and } \\
\text { students. Describing design as a "negotiation between problem and solution through the } \\
\text { activities of analysis, synthesis and evaluation". }\end{array}$ & $\begin{array}{l}\text { Design process, problem and solution, } \\
\text { experiment }\end{array}$ & Mixed method & $\begin{array}{l}\text { Design and } \\
\text { innovation } \\
\text { management }\end{array}$ \\
\hline Verganti (2003) & $\begin{array}{l}\text { Illustrating the central role of designers for those corporations whose new product development } \\
\text { strategy is centred on radical design. Arguing that designers act as brokers of languages. }\end{array}$ & $\begin{array}{l}\text { Radical design-driven innovation, Italian } \\
\text { design, design consultant }\end{array}$ & Qualitative & $\begin{array}{l}\text { Design } \\
\text { management }\end{array}$ \\
\hline Utterback et al. (2006)* & $\begin{array}{l}\text { Arguing that design-inspired innovation requires creativity of a higher order, whether the } \\
\text { products are professional tools, machinery for production, consumer goods, or services. } \\
\text { Suggesting that products succeed because they are associated with value-enhancing software } \\
\text { and services, thus what the user remembers is a delightful experience with the entire package, } \\
\text { and not whether that experience was provided or enabled by any particular aspect of design. }\end{array}$ & $\begin{array}{l}\text { Design-inspired innovation, product } \\
\text { innovation }\end{array}$ & Mixed method & $\begin{array}{l}\text { Design and } \\
\text { innovation } \\
\text { management }\end{array}$ \\
\hline Perks (2007) & $\begin{array}{l}\text { Investigating the relationship between the nature of interfunctional integration and industrial } \\
\text { new product/service portfolio decision making. Two critical interfunctional dimensions - } \\
\text { functional domination and nature of evaluation criteria - are derived and discussed, along with } \\
\text { managerial implications. }\end{array}$ & $\begin{array}{l}\text { Interfunctional integration, new product } \\
\text { portfolio decision making }\end{array}$ & Qualitative & $\begin{array}{l}\text { Innovation } \\
\text { management }\end{array}$ \\
\hline Verganti (2008) & $\begin{array}{l}\text { Proposing the use of a metamodel for the investigation of design-driven innovations. In it, } \\
\text { manufacturers' ability to understand, anticipate, and influence the emergence of new product } \\
\text { meanings is built by relying on external interpreters (e.g., designers, firms in other industries, } \\
\text { suppliers, schools, artists, and the media) who share, and contribute to, firms' problem solving. }\end{array}$ & $\begin{array}{l}\text { Design-driven innovation, meanings, } \\
\text { interpreters, manufacturing firms }\end{array}$ & Qualitative & $\begin{array}{l}\text { Innovation } \\
\text { management }\end{array}$ \\
\hline Brown (2008) & $\begin{array}{l}\text { Stressing three basic premises of the 'new' design thinking approach: design thinking is } \\
\text { equally relevant for designing products and spaces as well as systems or services; the primary } \\
\text { goal of design thinking is disruptive innovation to gain competitive advantage on the global } \\
\text { market; design thinking is human-/user-centred, and as such, can be done by different people } \\
\text { other than designers. }\end{array}$ & Design thinking & Qualitative & $\begin{array}{l}\text { Strategic } \\
\text { management }\end{array}$ \\
\hline Martin (2009)* & $\begin{array}{l}\text { Suggesting that firms should follow a design thinking paradigm by approaching managerial } \\
\text { problems in the same way designers approach design problems. }\end{array}$ & Design thinking, competitive advantage & Qualitative & $\begin{array}{l}\text { Strategic } \\
\text { management }\end{array}$ \\
\hline Dell'Era et al. (2010) & $\begin{array}{l}\text { Exploring design as a central part of the business process by focusing on the interplay } \\
\text { between the functional and semantic dimensions of a product. Drawing on two leading Italian } \\
\text { companies in the furniture industry, Kartell and Luceplan, to illustrate two principal } \\
\text { interpretations of the role of technology in design-driven innovation: technology as an enabler } \\
\text { of new product meanings for the customer, and the importance of supply networks that allow } \\
\text { manufacturers to change product technologies quickly and experiment new technologies. }\end{array}$ & $\begin{array}{l}\text { Innovation management, product } \\
\text { aesthetics, Kartell, Luceplan }\end{array}$ & Qualitative & $\begin{array}{l}\text { Technology } \\
\text { management }\end{array}$ \\
\hline Cross (2011) * & $\begin{array}{l}\text { Develop an understanding of how designers think and work. The book could trigger the } \\
\text { interest of design students, design researchers or teachers, managers within design-oriented } \\
\text { companies, or even designers who still find their own processes mysterious or difficult. The } \\
\text { book provides some insight into what it means to be a designer, how designers employ } \\
\text { creative thinking skills, and what is known about different aspects of design ability and its } \\
\text { development from novice student to expert professionals. }\end{array}$ & $\begin{array}{l}\text { Design ability, design thinking, } \\
\text { design professionals }\end{array}$ & Qualitative & $\begin{array}{l}\text { Innovation and } \\
\text { design studies }\end{array}$ \\
\hline
\end{tabular}

(1) All sources are academic journals unless otherwise specified (* for 'book', ' for 'working paper', ' for 'conference proceedings'). 


\section{Appendix Table 2 (continued)}

\begin{tabular}{|c|c|c|c|c|}
\hline Publication $^{(1)}$ & Focus & Keywords & Methodology & Field(s) \\
\hline \multicolumn{5}{|c|}{ Design and the value creation processes of the firm (please refer to Section 3.3 of the manuscript) } \\
\hline Roy and Potter (1990) & $\begin{array}{l}\text { Showing the results of a major study of the benefits and costs of investment in design in small- } \\
\text { and medium-sized manufacturing firms. }\end{array}$ & Design investment, SMEs & Quantitative & $\begin{array}{l}\text { Technology } \\
\text { management }\end{array}$ \\
\hline Walsh et al. (1992)* & Describing and analysing how good product design can contribute to firms' profitability. & $\begin{array}{l}\text { Design, technology, product design, } \\
\text { international competitiveness }\end{array}$ & Mixed method & $\begin{array}{l}\text { Design, innovation } \\
\text { management }\end{array}$ \\
\hline $\begin{array}{l}\text { Cooper and Kleinschmidt } \\
\text { (1995) }\end{array}$ & $\begin{array}{l}\text { Understanding company-level drivers of NPD success. Identifying NPD performance measures } \\
\text { and reducing them to two dimensions: program profitability and program product. }\end{array}$ & $\begin{array}{l}\text { New product development, success factors } \\
\text { profitability, program product }\end{array}$ & Quantitative & $\begin{array}{l}\text { Innovation } \\
\text { management }\end{array}$ \\
\hline Hertenstein et al. (2005) & $\begin{array}{l}\text { Examining the relationship between industrial design and company financial performance in } \\
\text { order to assess industrial design's contribution to this performance. Illustrating how good } \\
\text { industrial design is related to corporate financial performance and stock market performance } \\
\text { even after considering expenditures on industrial design. }\end{array}$ & $\begin{array}{l}\text { Industrial design, corporate financial } \\
\text { performance }\end{array}$ & Quantitative & $\begin{array}{l}\text { Innovation } \\
\text { management }\end{array}$ \\
\hline Candi (2006) & $\begin{array}{l}\text { Developing a model for evaluating the emphasis technology-based firms put on design. } \\
\text { The study of innovation draws upon a synthesis approach in the context of both services and } \\
\text { manufacturing as well as a three-dimensional definition of design. }\end{array}$ & $\begin{array}{l}\text { Innovation, design, technology-based } \\
\text { firms, performance }\end{array}$ & Mixed method & $\begin{array}{l}\text { Innovation } \\
\text { management }\end{array}$ \\
\hline Chiva and Alegre (2009) & $\begin{array}{l}\text { Analysing the effect of design investment on company performance and how this relationship } \\
\text { is mediated by design management skills. Suggesting that: design management enhances firm } \\
\text { performance, investing in design is positively related to design management, and that design } \\
\text { management contributes to determining the effects of design investment on firm performance. }\end{array}$ & $\begin{array}{l}\text { Design management, firm performance, } \\
\text { design investment }\end{array}$ & Quantitative & $\begin{array}{l}\text { Innovation } \\
\text { management }\end{array}$ \\
\hline $\begin{array}{l}\text { Candi and Saemundsson } \\
\text { (2011) }\end{array}$ & $\begin{array}{l}\text { Investigating the conditions under which the use of aesthetic design as an element of new } \\
\text { service development is likely to improve performance. Suggesting that practitioners should } \\
\text { consider using aesthetic design to counteract commoditisation when the markets in which they } \\
\text { compete are characterised by ready access to services that meet customers' needs and } \\
\text { expectations for features, performance, and reliability, expectations that have not been met yet. }\end{array}$ & $\begin{array}{l}\text { Aesthetic design, new service } \\
\text { development, firm performance }\end{array}$ & Quantitative & $\begin{array}{l}\text { Innovation } \\
\text { management }\end{array}$ \\
\hline Filippetti (2011) & $\begin{array}{l}\text { Investigating innovation modes by exploring design as a source of innovation. Suggesting that } \\
\text { design and R\&D are complementary sources of innovation and that design is predominant in } \\
\text { firms characterised by a complex innovation strategy and intense interactions with the external } \\
\text { environment, and that these types of firms also show better economic performance. }\end{array}$ & Innovation, design, companies & Quantitative & $\begin{array}{l}\text { Innovation } \\
\text { management }\end{array}$ \\
\hline $\begin{array}{l}\text { Moultrie and Livesey } \\
\text { (2013) }\end{array}$ & $\begin{array}{l}\text { Presenting a conceptual framework for the measurement of design investment and applying } \\
\text { this framework in a survey of UK firms. Describing design as being part of the creation and } \\
\text { commercialisation of new products and services. Proposing a revised framework that situates } \\
\text { design investment in the context of R\&D. Providing implications for policy makers trying to } \\
\text { understand the role and scale of design in the private sector, for managers wishing to optimise } \\
\text { their design investments, and for academics seeking to measure the value generated by design. }\end{array}$ & $\begin{array}{l}\text { Design investment, valuing design, } \\
\text { design, } R \& D \text { and innovation }\end{array}$ & Mixed method & $\begin{array}{l}\text { Innovation } \\
\text { management }\end{array}$ \\
\hline
\end{tabular}

${ }^{(1)}$ All sources are academic journals unless otherwise specified (* for 'book', ' for 'working paper', ' for 'conference proceedings'). 